\title{
Does the Gross Spread Compensate Lead Underwriters for Analyst Coverage?
}

\author{
Cheolwoo Lee \\ Accountancy, Finance, \& Info Systems Department, \\ College of Business, Ferris State University \\ 119 South Street, BUS 366, Big Rapids, MI 49307, USA \\ Tel: 1-231-592-2432Ｅ-mail: cheolwoolee@ferris.edu
}

Received: May 15, 2012

doi:10.5430/afr.v1n2p36
Accepted: June 7, 2012

Online Published: July 3, 2012

URL: http://dx.doi.org/10.5430/afr.v1n2p36

I thank Anup Agrawal, Hsuan-Chi Chen, Doug Cook, Junsoo Lee, James Ligon, Jay Ritter, Mary Stone, and seminar participants at the 2007 FMA, 2009 EFA, 2009 SFA, and 2010 AEF meetings for helpful comments and Hoseong Kim for SAS programming assistance on the construction of the prior relationship variables (The SAS program would be available upon request). I also gratefully acknowledge the contribution of Thomson Financial for providing Broker Recommendations data, available through the Institutional Brokers Estimate System, and the additional information on the definitions of the syndicate participants provided by the SDC data team.

\begin{abstract}
Since underpricing and gross spread are the two main revenue sources for investment banks in public offerings and Cliff and Denis (2004) find that underpricing is used to compensate analyst coverage, this paper examines the IPO syndicate data to investigate whether the gross spread compensates investment banks for analyst coverage. We find evidence to support the premise that the gross spread is used to compensate lead underwriters for analyst coverage when the lead underwriter has a strong bargaining power to advantageously shape up the compensation structure. After accounting for several critical issues, our results remain unchanged.
\end{abstract}

Keywords: Gross spread, Analyst coverage, Underwriter compensation, IPO, Fixed economics

\section{Introduction}

Initial public offerings (IPOs) can be a very lucrative business for investment bankers whose main revenues are generally realized in the explicit form of gross spread in combination with implicit underpricing (Note 1). Cliff and Denis (2004) find that underpricing compensates lead underwriters for analyst coverage (Note 2). They acknowledge that underwriter fees (gross spread) could be used as compensation but rule out this possibility since the overwhelming majority of gross spreads are uniformly clustered at 7\% (Chen and Ritter 2000). However, what really affects the lead underwriter compensation will be how much the lead underwriter receives out of the gross spread rather than the size of the gross spread. In this paper, we investigate whether the lead underwriter analyst coverage is compensated from the gross spread.

Although a $7 \%$ gross spread is widespread, splitting it into three components-management fee, underwriting fee, and selling concession - could cause a significant variation in how much each underwriter receives from the gross spread (Note 3). Torstila (2001) quotes the head of the equity syndicate desk at J. P. Morgan saying "For every minute spent negotiating the gross spread with the client, we probably spend well over 20 times negotiating the split of the gross spread among the various underwriters and co-managers" (Picker 1998). Tim Main, a member of the J. P. Morgan equity syndicate group, says "Everyone [every underwriter] is grabbing for the most money [fee income from the gross spread] they can on every deal...It can get very unfriendly" (Wirth 1997). Given that there is such fierce negotiation over the fee split, we think it plausible that the gross spread split can be used to compensate the lead underwriter for analyst coverage (Note 4). Furthermore, Ellis et al. (2000) find that underwriter profits in IPOs come mostly from the gross spread.

In contrast to Cliff and Denis, Aggarwal et al. (2002) document that analyst coverage by non-lead underwriters is positively related to underpricing while the lead underwriter's coverage is not related. They interpret their result as 
evidence that recommendations by the lead underwriter are included in basic underwriting services. Aggarwal et al.'s (2002) interpretation further empowers the validity of our investigation because valuable services are highly likely to be priced into the gross spread.

Our paper investigates whether the gross spread compensates the lead underwriter for analyst coverage. Since there is no public disclosure concerning the gross spread among syndicate members (Chen and Ritter 2000), we construct a payoff function that is dependent on incentives and observable data. Based on this function, we show that if the gross spread is used to compensate the lead underwriter for analyst coverage, then the underwriting fee (selling concession) proportion should be negatively (positively) related to analyst coverage while the management fee proportion should not be related to analyst coverage.

Our payoff function that utilizes the numbers of shares underwritten and credited for sales jointly with the gross spread split, therefore, is irrelevant to the evaluation of the underwriter compensation after the widespread introduction of the fixed economics (Note 5), presumably since late 1990s. For this reason, we perform sub-sample period analyses to see if there is any structural difference before and after the introduction of the fixed economics. We evaluate the existence of the lead underwriter compensation for analyst coverage using underwriting commitment for the period after the introduction of fixed economics in which underwriting commitment normally represents the size of the underwriter compensation from the gross spread.

Using the entire sample period, we find no evidence that the management fee is related to analyst coverage as we expected. Contrary to our model's prediction, however, we find no evidence for underwriting fee and selling concession that the gross spread compensates lead underwriters for providing analyst coverage. Analyst coverage by the lead underwriter shows no significant relation to all three fees when the entire sample period (October 1993-June 2002) is used.

Next, we perform sub-period analyses by splitting our sample period into the pre-fixed economics period (October 1 1993-June 16 1998) and the fixed economics period (June 17 1998-June 30 2002). We conduct the Quant-Andrews unknown breakpoint test to capture the timing of the fixed economics in section Regressions and the results suggest that the point of the structural break is June 16 1998, which coincides with the timing of the widespread growth of the fixed economics in bond offerings (Garrity and O'Leary 1999) (Note 6). For the pre-fixed economics period, we find evidence consistent with our payoff model's prediction when the lead underwriter has a high bargaining power to advantageously shape up the gross spread split. The analyst coverage by the lead underwriter is negatively (positively) related to underwriting fee (selling concession), which jointly increases the lead underwriter's payoff. For the fixed economics period, results are insignificant as in the entire sample period analysis. Such results suggest that, before the fixed-economics period, underwriter compensation from the gross spread depends on how much each underwriter underwrites and sells in conjunction with the gross spread split but, in the fixed economics period, the gross spread split became irrelevant for underwriter compensation due to a different compensation scheme- the fixed economics. Given the introduction of fixed economics during our sample period, it is natural that we find no significant result for the entire sample period.

For the fixed economics period, we use underwriting commitment to examine the underwriter compensation, instead of using the gross spread split information. After controlling for critical control variables, we find that the analyst coverage by the lead underwriter is positively associated with underwriting commitment when the lead underwriter has a large bargaining power, which is exactly the same implication as when we use the payoff function to evaluate underwriter compensation for the pre-fixed economics period. In sum, we use the gross spread split information for the pre-fixed economics period and underwriting commitment for the fixed economics period to evaluate the existence of the underwriter compensation for analyst coverage from the gross spread. We find consistent evidence in both sub-periods that the gross spread compensates the lead underwriter for analyst coverage when the lead underwriter has a high bargaining power that allows the lead underwriter to advantageously shape up the compensation structure on the gross spread. The reason that a strong bargaining power matters for the underwriter compensation from the gross spread would be because the gross spread split is entirely shaped within the syndicate only while underpricing can be affected by both underwriters' intentional pricing and aftermarket trading activity by investors in the market that are not under complete control of the underwriters.

As a robustness check, we address several issues. First, $\mathrm{I} / \mathrm{B} / \mathrm{E} / \mathrm{S}$ solely does not capture all the recommendations (Bradley et al. 2008). Similar to Bradley et al. (2008), we combine recommendations from I/B/E/S, First Call, and Briefing.com together to see if our main results stay the same. Second, we address the endogeneity issue of analyst coverage using the treatment-effects model with Heckman's two step procedure. Third, we construct prior relationship variables and add them in the estimation to see if adding them makes a difference to our main findings 
because Corwin and Schultz (2005) find that prior relationship is the most important determinant for syndicate participation. Fourth, we examine all-star analyst coverage. Our main results remain unchanged after accounting for these issues.

The contributions of this paper are twofold. First, we find that the gross spread compensates lead underwriters for providing analyst coverage when the lead underwriter has a large bargaining power. Second, we provide an alternative explanation for Torstila's (2001) main result that selling concession increases in the size of an IPO, measured by gross spread or offer proceeds. Torstila attributes this result to the differences in economies of scale and bargaining power. However, in association with our payoff function, this result can also be more intuitively explained by the fact that larger IPOs with more prestigious underwriters will advantageously split the gross spread.

We organize the rest of the paper as follows. Section II discusses our paper's relation to prior literature, reviews syndicate economics and develops hypotheses. Section III describes the data selection process. We report descriptive statistics and empirical results in Section IV and conclude in Section V.

\section{Prior Literature, Syndicate Economics, and Hypotheses}

\subsection{Prior Literature}

Although there is a broad literature on analyst coverage, relatively little has been written concerning the gross spread. Research on the split of the gross spread is quite limited although several papers document the clustering of the gross spread (Note 7). Torstila (2001) examines the gross spread split within a syndicate but does not address this split with respect to underwriter compensation. Instead, Torstila analyzes the gross spread split among syndicate members with respect to IPO size, first-day return, and several proxies for bargaining power and offering risks. His main result is that the percentage selling concession increases in IPO size while management and underwriting fees decrease with size.

Using French IPO data, Chahine (2002) finds a tradeoff between the gross spread and underpricing. However, applicability to the U.S. market is questionable since, unlike the U.S. market, French IPO gross spreads are not clustered. For example, Chahine's standard deviation of the French gross spread is 0.0314 while our U.S. sample has a standard deviation of only 0.005 . In addition, Chahine's sample includes only young, small-sized French IPOs.

\subsection{Syndicate Economics}

Fixed economics recently became common in underwriting business (Jenkinson and Jones 2007). Under the fixed economics, the deal economics using the gross spread split is irrelevant to underwriter compensation since underwriter compensation is made presumably independent of the gross spread split into three components. Therefore, we provide two separate syndicate economics: deal economics before the fixed economics and the fixed economics.

\subsubsection{Deal Economics before the Advent of Fixed Economics (Note 8)}

The Agreement Among Underwriters (AAU) partitions the gross spread into three major fees-management fee, underwriting fee, and selling concession - but does not disclose to the public the split of each fee among the underwriters.

The management fee, which used to be $15 \%$ until the late 1960 s, is now approximately $20 \%$ of the gross spread and is used to compensate the managing group - lead underwriters and co-managers - in return for documentation, road-show, marketing efforts, assessment of market conditions and proper IPO timing, and other investment banking services. Although the distribution of this fee among the managing group is determined through negotiation, the lead underwriter heavily influences the outcome (e.g., Barzel et al. 2000; Corwin and Schultz 2005).

The underwriting fee rewards underwriters for making capital commitments (bearing underwriting risk) and hovers between 20 and $30 \%$ of the gross spread. It is shared among all underwriters-lead underwriters, co-managers, syndicate members - based on a pro rata basis of underwriting commitments. Underwriting expenses are usually charged against this fee. Chen and Ritter (2000) contend that this fee could be negative when stabilization expenses, which are part of underwriting expenses, are high but Aggarwal (2000) provides evidence that stabilization expenses are actually quite small. In the case where underwriting expenses should exceed the underwriting fee, the lead underwriter, if authorized in the AAU, could bill co-underwriters for the loss pro-rata based on the magnitude of each underwriting commitment.

The selling concession usually ranges from 50 to $60 \%$ and compensates all sellers of a new issue: lead underwriters, co-managers, syndicate members, and non-underwriters in the selling group. The selling group consists of underwriters - lead underwriter, co-managers, and syndicate members - and non-underwriters (selected dealers). 
Instead of selling all their shares, some underwriters may choose selected dealers who have different client bases and distribution channels. If these selected dealers distribute a new issue, they will earn a portion of the sales credit (selling concession) based on actual sales of the security. Each underwriter buys allocated shares from the underwriting account at the offering price net of the selling concession. Share allocation substantially affects the fee that an underwriter receives (Corwin and Schultz 2005). However, earned sales credit is distorted by lead underwriter allocations. Since lead underwriters typically credit more sales to their account than the shares they underwrite (Chen and Ritter 2000; Torstila 2001; Corwin and Schultz 2005), the remainder of the syndicate normally receive credit for fewer shares than they underwrite (Note 9).

Aside from the lead underwriter's discretion, there is another but less influential factor that affects the relationship between shares allocated and sales credited. According to the Capital Markets Handbook, institutional investors usually buy their shares from the institutional pot and can request the lead underwriter to credit the selling concession for those shares to their designated investment banks (Note 10). These designated investment banks can be underwriters in the managing group, selling group, or even investment banks that do not participate in the syndicate. Such orders are referred to as "designated orders" and also known as directed orders or MBD (manager bill and deliver) orders.

Notwithstanding allocation distortions, we conjecture that there will be a substantial correlation between shares underwritten and sales credited since a sizeable gap between these might reduce the motivation of syndicate members to exert a substantial effort to ensure a successful IPO or discourage potential underwriters to join the syndicate (Kuhn, 1990). Perhaps this incentive compatibility issue is why negotiating the gross spread split consumes so much investment banker time.

\subsubsection{Fixed Economics (Note 11)}

So-called "fixed economics" became prevalent in the underwriting industry by the late 1990s. Jenkinson and Jones (2007) mention that 'fixed economics' has recently become prevalent and underwriter compensation from the gross spread is made in pro-rata basis according to underwriting fraction. It is also found in Hu and Ritter (2007) and other industry publications such as Garrity and O’Leary (1999), Keegan (1999a; 1999b), Critchley (2001), and Tunick and Hahn (2001). After the conversation with his investment banker friend, Jay Ritter also confirmed that "fixed economics" became common by the late 1990s.

Garrity and O'Leary (1999) and Keegan (1999a) report that 100\% pot distribution system is popular in bond offerings and gains its widespread popularity in the second half of 1998. Under this allocation structure, the lead underwriter possesses all controls over the allocation. Garrity and O’Leary (1999) and Keegan (1999a) note that it affects the gross spread since this practice includes the fixed economics where co-managers receive a fixed portion of the gross spread irrespective of whether to place bonds or not. For equity offerings, we observe a fairly similar allocation practice. Lead underwriters usually allocate themselves the majority of the shares, leaving a small number of shares to be allocated among co-managers and syndicate members; unless it is a cold deal, just few shares are typically allocated for sales to co-managers and syndicate members even hardly allocate any shares (Hu and Ritter 2007). Given that majority of shares are allocated by the lead underwriter and cold IPOs are rare, then there is little room for selling concession to come into play since selling concession goes to each underwriter based on their allocated shares for sales (Note 12). The prevalence of the fixed economics in equity offerings in the late 1990s is believed to be driven from the fact that gross spread split becomes useless as an effective gadget for underwriter compensation due to the dominant allocation by the lead underwriter as in bond offerings. In line with such inference, Jenkinson and Jones (2007) and Hu and Ritter (2007) note the prevalence of the fixed economics in equity offerings. The reason that IPOs still provide the gross spread split into three fees in AAU would be because, although rare, some cold IPOs might need selling concession and it is not anticipated with certainty ex ante whether an IPO will be hot or cold.

Suppose that a syndicate has one lead and two co-managers with no syndicate member for simplicity and that the fixed economics split is $70 / 15 / 15$, respectively. Under the fixed economics, each underwriter receives a portion of the gross spread proportional to the actual fixed economics split. Each normally underwrites as much as their portions in the fixed economics split. Therefore, underwriting commitment can work as a proxy for underwriter compensation from the gross spread in the fixed economics period. For example, if the gross spread for the exemplary syndicate above is $\$ 7$ million and road show costs $\$ 1.2$ million and other costs are $\$ 0.8$ million, the net gross spread for the fixed economics will be $\$ 5$ million and the lead underwriter in this example will receive $\$ 3.5$ million out of the gross spread and also underwrite $70 \%$ of the shares because it receives $70 \%$ of the gross spread in this IPO. Each co-manager will receive $\$ 0.75$ million and accordingly underwrites $15 \%$ (Note 13 ). 
As shown above, under the fixed economics, the gross spread split may have nothing to do with underwriter compensation since the split into management fee, underwriting fee, and selling concession might be merely a cosmetic representation and the actual underwriter compensation is determined by the fixed economics split. The gross spread split affects underwriter compensation in the pre-fixed economics period but in the fixed economics era what actually matters for the compensation will not be the gross spread split but the fixed economics split or, equivalently, the size of underwriting commitment.

\subsection{Hypotheses}

\subsubsection{Testable Hypotheses in the Pre-fixed Economics Period}

Analyst coverage is costly and the investment bank's reputation is placed at risk in case of faulty recommendations. Therefore, this activity should be rewarded accordingly. Since the management fee compensates investment bankers for explicit efforts such as documentations, road shows, and overall strategies, and since most of these activities are performed by the lead underwriter, it is not likely that the management fee will be used to compensate for analyst coverage.

\section{H1: Management fee is not related to analyst coverage affiliated with the lead manager.}

Given the relatively stationary $20 \%$ management fee, the remaining $80 \%$ will be split between the underwriting fee and selling concession. Thus, higher (lower) proportional underwriting fees result in lower (higher) proportional selling concessions. It is conceivable that pre-commitment for active analyst coverage is rewarded in the form of more shares underwritten or more sales credited to committed underwriters. A larger number of underwritten shares will increase the underwriting fee while a greater amount of credited sales will enhance the selling concession. We can write a total payoff function for underwriter $i$ of IPO $j$ as:

$$
\begin{aligned}
& \text { Payoff }_{i j}=\text { Offer Price }_{j} \times \% \text { Gross Spread }_{j} \times\left\{\text { No of Shares Issued }{ }_{j} \times \alpha_{i j} \times \% M F_{j}\right. \\
& \left.+ \text { No of Shares Underwritten } i j \times \% U F_{j} \times\left(1-\% U E_{j}\right)+\text { No of Shares Credited for } \text { Sales }_{i j} \times \% S C_{j}\right\}
\end{aligned}
$$

where No of Shares Issued ${ }_{j}$ is the overall number of shares issued for IPO $j ; \alpha_{i j}$ is the fraction that underwriter $i$ receives from the management fee on IPO $j$ and is a function of the lead underwriter's discretion; $\% M F_{j}$ is the management fee as a proportion of gross spread; No of Shares Underwritten ${ }_{i j}$ represents the number of shares underwritten by underwriter $i$ on IPO $j ; \% U F_{j}$ equals the underwriting fee as a proportion of gross spread; $\% U E_{j}$ is the proportion of underwriting expenses relative to the underwriting fee; No of Shares Credited for Sales $i j$ represents the number of shares credited for sales to underwriter $i$ on IPO $j ; \% S C_{j}$ is the selling concession as a proportion of gross spread; and $\% M F_{j}+\% U F_{j}+\% S C_{j}=1$. Rearranging the equation after replacing $\% S C_{j}$ with $1-\% M F_{j}-\% U F_{j}$ gives the following equation:

$$
\begin{aligned}
& \text { Payoff }_{i j}=\text { Offer Price }_{j} \times \% \text { Gross Spread }_{j} \\
& \quad \times\left\{\left[\text { No of Shares } \text { Issued }_{j} \times \alpha_{i j}-\text { No of Shares Credited for Sales }_{i j}\right] \times \% M F_{j}\right. \\
& \quad+\left[\text { No of Shares } \text { Underwritten }_{i j} \times\left(1-\% U E_{j}\right)-\text { No of Shares Credited for Sales } \text { S }_{i j}\right] \times \% U F_{j} \\
& \left.\quad+\text { No of Shares Credited for Sales } \text { S }_{i j}\right\}
\end{aligned}
$$

Equation 2 shows that the effect on payoff of increasing or decreasing the underwriting fee proportion of gross spread is a function of the relative size of shares underwritten and sales credited to the underwriter. When shares underwritten, net of expenses, are smaller (larger) than sales credited, decreasing (increasing) the underwriting fee proportion would provide more (less) profit for the underwriter. The opposite association applies to the selling concession because in this case $d \% S C_{j} / d \% U F_{j}<0$. Since the amount of sales credited for lead underwriters is typically larger than shares underwritten (e.g., Chen and Ritter 2000; Torstila 2001; Corwin and Schultz 2005) (Note 14), decreasing (increasing) the underwriting fee proportion (selling concession proportion) should enhance their compensation from the gross spread for any value that $\% U E_{j}$ takes $\left(\partial\right.$ Payoff $/ \partial \% U F_{j}<0$ and $\partial$ Payoff $\left./ \partial \% S C_{j}>0\right)($ Note 15). Thus, it is conceivable that the allocation of gross spread might be used to compensate lead underwriters for analyst coverage.

H2. Decreased (increased) underwriting fee (selling concession) proportion compensates lead underwriters for analyst coverage.

\subsubsection{Testable Hypothesis in the Fixed Economics Period}

Under the fixed economics, underwriter compensation will not bear any relation to the gross spread split. As discussed in section Syndicate economics, underwriter compensation in the fixed economics normally coincides with how much each underwrites. No one would deny that analyst coverage is costly to underwriters as well as valuable to 
the issuer and, therefore, should be compensated accordingly. Underwriting commitment-a measure for the underwriter compensation from the gross spread in the fixed economics period-will be determined considering the degree of underwriter services, including analyst coverage. Fixed economics means that underwriter compensation is fixed upfront but it does not mean that it is determined independent of how valuable services each underwriter provides. We believe that the fixed economics is a unifying product of negotiation within the syndicate. Analyst coverage will be adequately priced into the magnitude of underwriting commitment if compensated. Therefore, we expect that underwriting commitment is positively related to the analyst coverage by lead underwriters if analyst coverage is compensated from the gross spread.

H3. Lead underwriters underwrite more when they provide analyst coverage after controlling for other variables relevant to underwriter compensation if compensated.

Negotiation is central to how the gross spread and fixed economics splits are determined and bargaining power will shape up the negotiation within the syndicate. More bargaining power usually comes with more responsibility or commitment. We believe that lead underwriters will have a strong bargaining power when they take on more underwriting risk by underwriting more shares compared to co-managers. Such bargaining power will enable lead underwriters to shape up underwriter compensation advantageously to them. Therefore, we expect our hypotheses- $-\mathrm{H} 2$ and $\mathrm{H} 3$ - to be more pronounced in IPOs with heavy underwriting commitment by the lead underwriter. To examine such bargaining power dynamics, we split the sample into two groups based on the lead underwriter's relative share allocation.

H4. Hypotheses 2 and 3 are more likely in IPOs wherein lead underwriters underwrite more relative to co-managers.

\section{Data, Sample, and Variables of Interest}

\subsection{Sample}

We collect data to test our hypotheses by identifying 5,115 IPOs from October 1993 to June 2002 using Thomson Financial Securities Data Company (SDC) Platinum Global New Issues (Note 16). Consistent with prior research, we exclude non-U.S. firms, unit offerings, closed-end funds, non-common shares, financial services firms (classified as SIC 6000-6999), multiple lead underwriter IPOs, IPOs with management fees and underwriting fees combined, and IPOs whose offer proceeds are less than \$20 million. We remove 512 IPOs whose management fees and underwriting fees are combined since the split of the gross spread into three components is the main focus of this study. Purging IPOs below \$20 million eliminates penny stock IPOs (share price below \$5). We eliminate IPOs with multiple lead underwriters due to interpretation dissimilarities and methodological difficulties in constructing prior relationship variables. We also remove singly led IPOs. Finally, we exclude firms that are not covered in the Center for Research in Security Prices (CRSP) and the Institutional Brokers Estimate System (I/B/E/S). In some cases, we are able to complement missing information in SDC by obtaining prospectuses from the Securities and Exchange Commission's (SEC) Electronic Data Gathering and Retrieval (EDGAR) system and 10K Wizard (http://www.10kwizard.com). The final sample is 1,894 IPOs.

We obtain IPO-related information from SDC, stock price data from CRSP, and analyst recommendations data from the I/B/E/S Recommendations-Detail database. Since brokers and analysts are in abbreviated and numeric code formats, we use the Recommendation Broker Translation file to match the full names from abbreviated broker codes and identify whether IPOs have affiliated analyst coverage within 1 year of the IPO.

Managerial roles in SDC include six types of participants: bookrunner, joint bookrunner, joint lead manager, co-manager, syndicate member, and global coordinator (Note 17). Excluding multiple lead underwriter IPOs also excludes joint bookrunners. Although some IPOs have global coordinators and bookrunners are sometimes redundantly listed as global coordinators, the SDC data team indicates that global coordinators are not necessarily bookrunners. We ignore global coordinators since coordinating various events of the deal is deemed to be part of the bookrunner job (Note 18). The bookrunner is listed at the top of the "Underwriting" section in the prospectus and appears in the lower left corner of the prospectus cover. The bookrunner assumes most of the responsibility for and keeps records of syndicate activities - arranging syndicate formation, IPO timing, due diligence, roadshows, and share allocation to underwriters - and is primarily involved in the preparation of the registration statement, offer pricing through bookbuilding, share distribution, and aftermarket stabilization (Note 19). Joint bookrunners share the bookrunner functions equally with other joint bookrunners, which arrangement is stipulated by a signed letter. Although the joint lead manager typically sells as many shares as the bookrunner, it does not perform a book-running function. For U.S. deals, a co-manager is anyone who is listed on the prospectus cover but not identified as a lead 
manager (Note 20). Syndicate members are not on the prospectus cover but appear in the 'Underwriting' section. In this study, we group syndicate participants into three groups: lead underwriter (bookrunner), co-managers (joint lead managers and co-managers), and syndicate members.

We collect underwriter reputation ranks from Jay Ritter's web-site. We also obtain founding dates for the sample IPO firms from Jay Ritter's web-site and complement missing dates with the SDC firm age database as well as prospectuses on EDGAR. We match founding dates and sample firms based on PERMNO (5-digit CRSP permanent number). Finally, we construct an internet IPO dummy variable based on the list of Internet IPOs from Jay Ritter's web-site.

\subsection{Variables of Interest and Control Variables}

The main focus of this paper is to test whether the gross spread compensates lead underwriters for providing analyst coverage. We measure gross spread using the proportions of management fee, underwriting fee, and selling concession as dependent variables. We construct a dummy variable, Affiliated Coverage Dummy, that equals one if an IPO has a recommendation by any lead underwriter affiliated analyst and zero otherwise. Hypothesis 2 (3) suggests that if lead underwriters are compensated for analysis coverage then this dummy variable should have a negative (positive) association with the underwriting fee (selling concession) proportion. We also include control variables that have wide theoretical and empirical justifications in the literature and proxy for characteristics of issuers, IPOs, and underwriters:

$C M / L U$ Ratio: We construct the $\mathrm{CM} / \mathrm{LU}$ ratio - the ratio of shares allocated to co-managers to those to the lead underwriter (LU) - since the degree of capital commitment will affect the bargaining power involved in splitting the gross spread.

LU Reputation: High reputation underwriters are expected to exhibit a strong bargaining power within a syndicate with which they can effectively influence the spilt, extracting more from the gross spread. We expect high-reputation lead underwriters to be negatively (positively) associated with the underwriting fee (selling concession) proportion.

Gross Spread: If underwriting costs are mostly variable (fixed) as asserted by Altinkilic and Hansen (2000), then gross spread should be positively (negatively) related to the management fee. Since large issues require a higher degree of selling effort (Torstila 2001), we expect a positive (negative) relationship between gross spread and selling concession (underwriting fee) proportion.

No. of Co-managers: The number of co-managers represents the number of underwriters with which the lead underwriter shares a substantial portion of the gross spread. As this number increases and the lead underwriter's claim on the gross spread decreases, we expect that the lead underwriter will become more sensitive to the split, aggressively attempting to reduce (increase) the underwriting fee (selling concession) proportion.

Underpricing: Since higher underpricing is associated with hot IPOs (Torstila, 2001) and lower underwriting risk because hot IPOs are easier to sell, we expect higher underpricing to be associated with a lower (higher) underwriting fee (selling concession) proportion.

Aftermarket Stdev: We use aftermarket standard deviation as an ex post proxy for the risk associated with the issuer's uncertainty (e.g., Beatty 1989; Barry et al. 1991). Since higher underwriting risk should be compensated accordingly, we expect Aftermarket Stdev to be positively (negatively) related to the underwriting fee (selling concession) proportion.

Internet IPO Dummy: We control our analysis for the distinctive nature of internet IPO firms. Internet IPOs have higher initial returns - underpricing - and more prestigious underwriters - LU Reputation-(e.g., see DuCharme et al. 2001; Schultz and Zaman 2001). Higher underpricing will reduce underwriting risk while more reputable lead underwriters will increase the selling concession proportion.

\section{Empirical Results}

\subsection{Descriptive Statistics}

Figure 1 illustrates the distributions of gross spread and its three components. As documented in Chen and Ritter (2000), there is a clustering of gross spreads around 7\%. Panel B of Table 1 reports that 1,551 out of 1,894 IPOs have the exact 7\% gross spread. Chen and Ritter (2000) report in their Table 1 that the frequency of the exact 7\% gross spread increases over time. We find that the rising trend peaks at the end of 2000 . The exact $7 \%$ gross spread in our sample is $66 \%$ in $1993,82 \%$ in 1997 , rising to $89 \%$ in 2000 , but falling to $79 \%$ in 2001 and $78 \%$ in 2002 . Figure

1 shows that the management fee has the smallest variation in distribution. The underwriting fee appears to be an 
approximate mirror image of the selling concession, suggesting that there might be tradeoffs between them; the fat tail of the underwriting fee is on the right while that of the selling concession is on the left.

Panel A of Table 1 provides sample characteristics while Table 2 shows how average characteristics have changed over time. The split into three fees is fairly close to the standard 20/20/60 split and an average syndicate has approximately 2 co-managers and 8 syndicate members. Each IPO on average receives 7.44 recommendations for 1 year after going public and 0.88 recommendation from the lead underwriter affiliated analysts. Analyst coverage by lead underwriters takes up 16\% of all recommendations that IPOs receive. Panel B indicates that the majority of IPOs are listed on the NASDAQ and nearly half of them receive coverage by lead underwriter affiliated analysts within 1 year after going public.

Although the management fee is flat during the entire sample period, the underwriting fee drops slightly each year while the selling concession increases correspondingly since 1998. Consistent with Chen and Ritter (2000) and Corwin and Schultz (2005), the number of co-managers increases monotonically while the syndicate size stays very low until 1996, jumps up to 19.09 in 1997, and decreases thereafter (Note 21). Such a big jump between 1996 and 1997 might be due to the incompleteness in SDC syndicate data earlier than 1997 as noted by Corwin and Schultz (2005). The yearly breakdown for the lead underwriter reputation rank shows some discrepancies with Corwin and Schultz (2005) but yearly trends are similar for the 1997-2002 period. The number of recommendations has increased over time, except for a small drop in 2000. IPOs with at least one LU recommendation range from $40 \%$ to $70 \%$, not exhibiting any monotonic trend over time.

In untabulated results we perform $t$-tests and Wilcoxon rank-sum tests for the 1993-2002 period to see if each fee differs as to whether IPOs receive recommendations from the lead underwriter but find no significant difference between the two groups tested by mean and median.

\subsection{Regressions}

In this section, we test our hypotheses regarding the relationship between gross spread component proportions and analyst coverage. Because the three equations with each fee as a dependent variable are not independent, it would be misleading to consider one of the three fees in isolation. To estimate the three fee equations simultaneously, taking correlated errors into account, we use the Seemingly Unrelated Regression (SUR) estimation. We include control variables that proxy for characteristics of issuers, offers, and underwriters. We also add year dummies and industry dummies to control for time trends and industry-specific effects.

\subsubsection{Multivariate Results: Overall Sample (October 1993-June 2002)}

Table 3 reports the results from the SUR estimation using the entire sample period. Since Torstila (2001) finds that gross fees (gross spread dollars) and gross fees squared are strong explanators of gross spread components, we also include these as explanatory variables. As expected, there is no evidence that analyst coverage is significantly related to the management fee proportion. Equation (2) indicates that decreasing underwriting fee and increasing selling concession will increase the lead underwriter's payoff for providing analyst coverage. In contrast with our prediction, however, we find no significant results for underwriting fee and selling concession. These results do not support the premise that the gross spread split is used to compensate lead underwriters for analyst coverage.

Unlike the result in Torstila (2001), LU reputation is a significant explanator for all three fees. The signs are consistent with prestigious lead underwriters enhancing their payoff by increasing selling concession at the expense of the other two fees. We also obtain the main result of Torstila where selling concession is positively associated with gross spread (IPO size). However, we can explain Torstila's main result by the fact that larger IPOs with more prestigious underwriters will advantageously split the gross spread. Underpricing is negatively (positively) associated with underwriting fee (selling concession), consistent with our expectation and Torstila's (2001) result.

\subsubsection{Fixed Economics in the Late 1990s (Note 22)}

According to Jenkinson and Jones (2007) and other industry publications, the fixed economics became common in the late 1990s, which is also confirmed by Jay Ritter's conversation with his investment banker friend. Unfortunately, the exact timing is not known for the prevalence of the fixed economics. To capture the timing of the unknown structural break, we employ the Quandt-Andrews unknown breakpoint test, an $F$-statistic approach suggested by Andrews (1993) and Andrews and Ploberger (1994). It tests the null hypothesis of no structural break whose alternative hypothesis is a single unknown breakpoint that exists. The test generates $k$ Chow $F$-statistics for a given time interval and aggregates these $F$-statistics into the test statistics in Table 4 where the results are summarized. The timing of the fixed economics suggested by the Quandt-Andrews unknown breakpoint test is June 16 1998, which also coincides with the timing that the $100 \%$ pot allocation with the fixed economics became widely popular in bond 
offerings (Garrity and O’Leary 1999). $P$-values are significant for all three statistics and in all intervals that we consider for the structural break.

Based on the Quandt-Andrews unknown breakpoint test results, we split our sample into two sub-periods: pre-fixed economics period (October 1 1993-June 16 1998) and fixed economics period (June 17 1998-June 30 2002). Our payoff function can be valid only before the fixed economics set in since gross spread split is irrelevant to the underwriter compensation under the fixed economics. Table 5 summarizes the univariate test results for the entire and two sub-sample periods - pre-fixed and fixed economics periods. Consistent with our expectation implied by the payoff function, the mean differences are significant for underwriting fee and selling concession in the pre-fixed economics period while it is not for management fee. However, we do not find any significant difference in underwriting commitment in neither the entire nor two sub-sample periods.

Since univariate tests do not account for issuer-specific and underwriter-specific attributes, we execute our analysis in the multivariate setup. To further incorporate additional information - bargaining power dynamics - into the analysis we also partition the sample into two sub-samples according to relative share allocations to the lead underwriter (CM/LU ratio). We partition our sample into "High" and "Low" based on the degree of share allocation to the lead underwriter. Specifically, the High sub-sample contains IPOs whose CM/LU ratio is less than the median while the other IPOs are in Low group. The CM/LU ratio is defined in Table 6.

Table 6 reports multivariate regression results in the pre-fixed economics period (October 1 1993-June 16 1998). We find results consistent with our model's prediction for the overall and High sub-samples while the Low sub-sample shows no significant result. Affiliated Coverage Dummy is negatively (positively) associated with underwriting fee (selling concession), which will jointly increase the lead underwriter's payoff from the gross spread. The results in Panel B of Table 6 are based on the High sub-sample where the lead underwriter underwrites relatively more than co-managers do, which probably entitles more bargaining power to the lead underwriter. These results imply that the gross spread is more likely to compensate the analyst coverage by the lead underwriter when the lead underwriter has a large bargaining power that facilitates an advantageous gross spread split.

We also employ the SUR estimation for the fixed economics period and find no significant results for the overall and two sub-samples. Given that the advent of the fixed economics in the late 1990s in which the gross spread split is presumably made independent of the actual underwriter compensation, it makes good sense that we do not find any significant result for the analyses using the entire sample period (October 1993-June 2002) and the fixed economics period. Such results confirm that our payoff function is legitimate only for the period before the fixed economics landed on the underwriting industry.

Table 7 reports logit regression results in the fixed economics period (July 17 1998-June 30 2002) using underwriting commitment as a proxy for underwriter compensation from the gross spread. We add a new variable, No. of Syndicate Members, to the logit estimation because the lead underwriter's underwriting commitment might be substantially influenced by more or fewer syndicate members who supposedly share the gross spread (underwriting commitment) through their participation with the lead underwriter and co-managers. As shown in Table 7, the lead underwriter's bargaining power comes into play. The coefficient for CM/LU Ratio in the first specification is negative and significant, suggesting that affiliated coverage is more likely when the lead underwriter receives a higher share allocation compared to co-managers, in which case the lead underwriter would have more underwriter compensation in the fixed economics period. Such relationship is more pronounced when we include Underwriting Commitment as a measure for underwriter compensation. In the High sub-sample, analyst coverage by the lead underwriter is more likely when underwriting commitment is greater whereas no significant result is found in the overall sample and Low sub-sample. Coefficients in the logit regression are not the same as marginal effects in SUR estimation. Therefore, we calculate the marginal effect of Underwriting Commitment after holding all the other independent variables at their sample means to see how $1 \%$ increase in Underwriting Commitment affects the probability that the lead underwriter provides analyst coverage in the aftermarket. $1 \%$ increase in Underwriting Commitment in the third specification using the High sub-sample results in $2.87 \%$ higher chance of analyst coverage by the lead underwriter, which is significant at the $1 \%$ level ( $z$ statistic of 3.87). We observe exactly the same implication as in the pre-fixed economics period; analyst coverage by the lead underwriter is compensated from the gross spread when the lead underwriter has a larger bargaining power.

In summary, all preceding results suggest that lead underwriters shape up the gross spread split for the pre-fixed economics period and the underwriting commitment for the fixed economics period in favor of themselves when they provide analyst coverage and, at the same time, have a strong bargaining power to allow them to advantageously shape up the compensation structure on the gross spread. 


\subsection{Robustness Checks}

In this section, we address four critical issues that might affect our main findings: the I/B/E/S's incomplete capture of recommendations, endogeneity of analyst coverage, prior relationship in syndicate participation, and affiliated all-star analyst coverage.

\subsubsection{Does I/B/E/S Capture All or Majority of Recommendations? (Note 23)}

A closer look into our data suggests that lead underwriters generally provide a fairly small portion of overall recommendations for each IPO and approximately half of our sample IPOs do not even receive any recommendation from their lead underwriters during the first year after their IPOs. Panels A and B of Table 1 indicate that lead underwriters provides roughly $16 \%$ of the overall recommendations and that $52 \%$ of our sample IPOs receive at least one recommendation from the lead underwriter while the other $48 \%$ do not. Such inactive analyst coverage from the lead underwriter is also observed in some other papers. Iskoz (2003) has the similar observation in which 1,467 of 3,534 IPOs receive no LU recommendation. In other words, $58.5 \%$ receive at least one LU recommendation whereas $41.5 \%$ do not. Iskoz's average number of LU recommendations is 0.74 (2,630 recommendations $\div 3,534$ IPOs) and the average number of overall recommendations is $5.28(18,645 \div 3,534)$. Iskoz's and our sample are telling the same story: lead underwriters do not generally provide analyst coverage. We also construct the average number of LU recommendations based on Table 2 of McNichols et al. (2006), which is 0.79 (1,864 recommendations $\div 2,346$ IPOs). This leads us to suspect whether lead underwriters generally provide analyst coverage in IPOs.

Bradley et al. (2008) note that I/B/E/S solely does not capture all recommendations. For this reason, Bradley et al. (2008) use additional sources to identify recommendations such as Briefing.com, First Call, and Investext. Our low level of LU recommendations might be attributable to this fact. Similar to Bradley et al. (2008), we combine I/B/E/S, First Call, and Briefing.com together to test if our results are different between using $\mathrm{I} / \mathrm{B} / \mathrm{E} / \mathrm{S}$ only and using the combined data. As shown in Panel A of Table 8, we initially obtain 14,218 recommendations for 1,894 IPOs from I/B/E/S only. We manually identify additional 6,773 recommendations from First Call, which are not covered in I/B/E/S. Finally, searching on Briefing.com gives additional 443 recommendations not overlapping with I/B/E/S and First Call (Note 24). After combining all three data sources, the number of recommendations increases to 21,424. The number of recommendations per IPO goes from 7.4 to 11.3 after combining and the average coverage by the lead underwriter increases from 0.88 to 1.87 .

Now, $80 \%$ of our sample IPOs (1,508 IPOs) receive at least one recommendation from the lead underwriter. As suggested by this percentage, it is not easily justifiable to argue that lead underwriters generally do not provide analyst coverage since majority of the IPOs receive a LU recommendation. As pointed out by Bradley et al. (2008), when we solely use either $\mathrm{I} / \mathrm{B} / \mathrm{E} / \mathrm{S}$ or First Call, we can potentially experience a problem of data incompleteness, which may sometimes lead to a misleading conclusion.

Univariate tests based on the combined recommendations data show that differences of underwriting fee and selling concession between two groups are more pronounced while management fee shows no difference; IPOs with (without) LU analyst coverage for the fixed economics period on average have $21.45 \%(21.93 \%)$ underwriting fee and $58.19 \%(57.61 \%)$ selling concession and their differences are significant at the $1 \%$ level, respectively. IPOs with (without) affiliated coverage are on average 13.82 (11.31) years old, have $\$ 87$ (55) million offer proceeds and $\$ 14.49$ (13.57) offer prices, 8.09 (7.53) reputation ranks, and 34\% (27\%) underpricing.

Based on the combined recommendations data, we report the SUR estimation result for the pre-fixed economics period and the logit regression result for the fixed economics period in Table 9. The High sub-sample results only are reported because this sub-sample only shows significant results. Results in Panels A and B of Table 9 show the same implication as we find earlier with the $\mathrm{I} / \mathrm{B} / \mathrm{E} / \mathrm{S}$-only recommendations data. We find a negative (positive) significant coefficient on underwriting fee (selling concession) in Panel A and a positive coefficient on underwriting commitment in Panel B in relation to analyst coverage. Although the results in Table 9 have a slightly lower statistical significance compared to the earlier results in Tables 6 and 7, they are statistically significant enough to confirm our early results with $\mathrm{I} / \mathrm{B} / \mathrm{E} / \mathrm{S}$ only. Results in Table 9 suggest that our results are robust to the $\mathrm{I} / \mathrm{B} / \mathrm{E} / \mathrm{S}$ incompleteness issue and that recommendations on $\mathrm{I} / \mathrm{B} / \mathrm{E} / \mathrm{S}$ are representative to some extent although it does not capture all.

\subsubsection{Endogeneity of Analyst Coverage}

It is subject to criticism if we assume that analyst coverage is exogenous (e.g., Cliff and Denis 2004). The pre-commitment or provision of analyst coverage will be reflected in the process of negotiating over underwriting commitment (i.e., underwriter compensation), which brings up an endogeneity issue between analyst coverage and 
underwriting commitment. We address this endogeneity issue by controlling for the self-selection bias using the treatment-effects model with Heckman's two-step procedure (Note 25). In untabulated results, the instrumented Affiliated Coverage Dummy is positively related to Underwriting Commitment ( $2^{\text {nd }}$ stage dependent variable) at the $5 \%$ significance level although we do not find evidence of the endogeneity since the coefficient of parameter $\lambda$ (the inverse Mills ratio) is insignificant (Note 26). The coefficients of No. of Co-managers and No. of Syndicate Members are all negative for underwriting commitment and significant at the $1 \%$ level. Consistent with Corwin and Schultz's (2005) explanation on why syndicate size is limited, more co-managers and/or syndicate members require a certain amount of share allocation to them, which in turn leaves reduced share allocation (underwriting commitment) to the lead underwriter. In sum, after controlling for the self-selection bias in analyst coverage, we again find a positive association between analyst coverage and underwriting commitment for the High sub-sample, which is consistent with our earlier findings.

\subsubsection{Prior Relationships (Note 27)}

Corwin and Schultz (2005) find that prior (or reciprocal) relationships are the single most important determinant of syndicate participation and Pichler and Wilhelm (2001) assert "the syndicate's unique organizational structure reflects, at least in part, an institutional response to the 'relationship-intensive' nature of the investment banking industry." Ljungqvist et al. (2009) confirm Corwin and Schultz's findings using both debt and equity samples with more extended sample period. It is highly conceivable that the decision to participate in a syndicate is closely related to underwriters' incentive and compensation.

Although investment banks are eager to participate in the underwriting business because it is lucrative, there are barriers to entry (e.g., Pichler and Wilhelm 2001; Ljungqvist et al. 2009). Syndicate membership benefits less established banks by enhancing their reputation. In addition, reputation building as a co-manager may ultimately lead to a lead underwriter position (Ljungqvist et al. 2009). Therefore, co-managers may view syndicate participation as an investment with long-term potential payoffs and be motivated to exert sufficient selling efforts while foregoing some short-term compensation. This might facilitate a stronger bargaining position for the lead underwriter to carve up a favorable split of the gross spread. Thus, we expect that prior relationship will be decreasing (increasing) in the underwriting fee (selling concession) proportion. We run regressions with prior relationship variables added as control variables.

Similar to Corwin and Schultz (2005), we define four variables: where $L U_{l}$ is the proportion of participation for the current co-managers' appearances in the most recent IPO led by the current lead underwriter; $C M_{l}$ is the proportion of participation for the current lead underwriter in most recent IPO led by the current co-manager(s); $L U_{I 0}$ is the proportion of participation for the current co-managers in the last 10 IPOs led by the current lead underwriter; $C M_{10}$ is the proportion of participation for the current lead underwriter in the last 10 IPOs led by current co-managers (Note 28).

Contrary to our expectation, we find little to no significant results for the prior relationship variables in all specifications. Our main results stay the same when these prior relationship variables are included as control variables using both the entire and two sub-samples - High and Low - in the pre-fixed and fixed economics periods. We find no evidence that prior relationship is an important determinant in shaping up the underwriter compensation from the gross spread in all sub-sample analyses although it is shown to be important in syndicate participation.

\subsubsection{All-star Analyst Coverage}

Issuers highly value all-star analyst coverage (e.g., Krigman et al. 2001; Dunbar 2000) and the market reaction is the most positive to all-star coverage (Stickel 1992). Furthermore, all-star coverage will probably be costlier (Hu and Ritter 2007). Providing such coverage will give underwriters a better bargaining position in sharing the gross spread. For this reason, we examine our research question based on all-star analyst recommendations. We define an all-star analyst as any analyst named on the first, second, or third teams of the All-American Research Team in the previous year's issue of the Institutional Investor. We use all-star analyst information from 1992 and 2001. The reason that we include 1992 and do not use 2002 is that, for example, all-star analysts in the 1992 Institutional Investor October issue are relevant to the all-star analyst consideration for IPOs that went public in 1993 because IPOs in 1993 have no information on that year's all-star analysts until October 1993. Since some analysts switched investment banks during the sample period, we match all-star analysts in Institutional Investor and I/B/E/S by using an analyst' last name and first name initial from the $\mathrm{I} / \mathrm{B} / \mathrm{E} / \mathrm{S}$ database in conjunction with the analyst' affiliated investment bank in the year of recommendation. When $\mathrm{I} / \mathrm{B} / \mathrm{E} / \mathrm{S}$ information is missing, we refer to the NASD BrokerCheck system and Google searches. 
We construct affiliated all-star analyst coverage as a dummy variable and run the SUR and logit regressions. In untabulated results, we find no significant results when we use it instead of Affiliated Coverage Dummy in the SUR and logit regressions. When we add the affiliated all-star coverage dummy as one of the control variables to the specifications in Tables 6 and 7, our main results stay unchanged. We also construct a co-manager all-star coverage dummy since the co-manager will have a better position in negotiating when they provide all-star coverage, which will further affect the lead underwriter's bargaining power. We add it to the estimations in Tables 6 and 7 as a control variable. Affiliated Coverage Dummy is significant at the 1\% level with the same signs in Panel A of Table 6 and Table 7 although the co-manager all-star coverage dummy is significant at the 5\% (10\%) level with a positive (negative) sign for underwriting fee (selling concession) in the SUR estimation and is not significant in the logit estimation. Unfortunately, such significant results for co-manager all-star coverage in the SUR estimation cannot be interpreted without certain assumptions due to insufficient information as noted in Note 15.

\section{Conclusion}

We attempt to explain whether the gross spread compensates the lead underwriter for providing analyst coverage during the period October 1993 to June 2002. As the fixed economics set in around the late 1990s, the gross spread split as a means for underwriter compensation became no longer valid since underwriter compensation became directly linked to the underwriting commitment, not to the gross spread split. The Quandt-Andrews unknown breakpoint test and other sources suggest that the fixed economics started industry-wide from mid-1998. For the period before the fixed economics set in (October 1 1993-June 16 1998), in the absence of direct compensation data, we construct a payoff function which shows that analyst coverage by lead underwriters should be compensated with a lower underwriting fee proportion and a higher selling concession proportion. For the period after the fixed economics became common industry-wide (June 17 1998- June 30 2002), we use underwriting commitment as a proxy for the compensation to evaluate the existence of the underwriter compensation from the gross spread.

In the sub-period analysis, we find evidence for the pre-fixed economics period consistent with our predictions; analyst coverage by the lead underwriter is negatively (positively) associated with underwriting fee (selling concession) - which increases the lead underwriter's payoff from the gross spread - when the lead underwriter has a large bargaining power in the syndicate. Such split will incent the lead underwriter to provide analyst coverage. For the fixed economics period (June 17 1998-June 30 2002), we find that analyst coverage by the lead underwriter is positively associated with underwriting commitment when the lead underwriter has a large bargaining power in a syndicate, which will enable the lead underwriter advantageously to shape up the compensation structure of the gross spread. Our results remained unchanged after accounting for I/B/E/S's incomplete capture of recommendations, endogeneity of analyst coverage, prior relationship in syndicate participation, and all-star analyst coverage. Unlike Cliff and Denis' (2004) conjecture, we find evidence irrespective of the introduction of the fixed economics that the analyst coverage by the lead underwriter is compensated also from the gross spread, not only from underpricing, consistent with the premise that the gross spread is a major source of revenues for investment banks in public offerings.

\section{References}

Aggarwal, R. (2000). Stabilization activities by underwriters after initial public offerings. Journal of Finance 55, 1075-1103. http://dx.doi.org/10.1111/0022-1082.00241

Aggarwal, R., Krigman, L., \& Womack, K. L. (2002). Strategic IPO underpricing, information momentum, and lockup expiration selling. Journal of Financial Economics 66, 105-137. http://dx.doi.org/10.1016/S0304-405X(02)00152-6

Altinkilic, O., \& Hansen, R. S. (2000). Are there economies of scale in underwriting fees? evidence of rising external financing costs. Review of Financial Studies 13, 191-218. http://dx.doi.org/10.1093/rfs/13.1.191

Andrews, D.W.K. (1993). Tests for parameter instability and structural change with unknown change point. Econometrica 61, 821-856. http://dx.doi.org/10.2307/2951764

Andrews, D.W.K., \& Ploberger, W. (1994). Optimal tests when a nuisance parameter is present only under the alternative. Econometrica 62, 1383-1414. http://dx.doi.org/10.2307/2951753

Barry, C.B., Muscarella, C.J., \& Vetsuypens, M.R. (1991). Underwriter warrants, underwriter compensation, and the costs of going public. Journal of Financial Economics 29, 113-135. http://dx.doi.org/10.1016/0304-405X(91)90016-D 
Barzel, Y., Habib, M.A., \& Johnsen, D.B. (2000). IPO syndicates, private foreknowledge, and the economics of excess search. George Mason Law \& Economics Research Paper No. 00-29.

Beatty, R.P. (1989). Auditor reputation and the pricing of initial public offerings. Accounting Review 64, 693-709.

Bradley, D.J., Jordan, B.D., \& Ritter, J.R. (2008). Analyst behavior following IPOs: the "Bubble Period" evidence. Review of Financial Studies 21, 101-133. http://dx.doi.org/10.1093/rfs/hhl028

Carter, R., \& Manaster, S. (1990). Initial public offerings and underwriter reputation. Journal of Finance 45, 1045-1067.

Chahine, S. (2002). Ex-ante gross spreads for small and medium sized IPOs. Audencia Nantes School of Management Working Paper.

Chen, H., \& Ritter, J.R. (2000). The seven percent solution. Journal of Finance 55, 1105-1132. http://dx.doi.org/10.1111/0022-1082.00242

Cliff, M.T., \& Denis, D.J. (2004). Do initial public offering firms purchase analyst coverage with underpricing? Journal of Finance 59, 2871-2901. http://dx.doi.org/10.1111/j.1540-6261.2004.00719.x

Corwin, S.A., \& Schultz, P. (2005). The role of IPO underwriting syndicate: pricing, information production, and underwriter competition. Journal of Finance 60, 443-486. http://dx.doi.org/10.1111/j.1540-6261.2005.00735.x

Critchley, B. (2001). Pluses and minuses of domtar deal: got its financing, but missed broader U.S. participation. National Post, National Edition, October 3.

DuCharme, L.L., Rajgopal, S., \& Sefcik, S.E. (2001). Why was internet IPO underpricing so severe? University of Washington Working Paper.

Dunbar, C.G. (2000). Factors affecting investment bank initial public offering market share. Journal of Financial Economics 55, 3-41. http://dx.doi.org/10.1016/S0304-405X(99)00043-4

Ellis, K., Michaely, R., \& O'Hara, M. (2000). When the Underwriter is the market maker: an examination of trading in the IPO aftermarket. Journal of Finance 55, 1039-1074. http://dx.doi.org/10.1111/0022-1082.00240

Garrity, B., \& O'Leary, C. (1999). Relentless forces erode fee structure: megamergers and hyper-competition are slowly eroding underwriting fees. Investment Dealers' Digest, February 1.

Hansen, B.E. (1997). Approximate asymptotic p values for structural-change tests. Journal of Business and Economic Statistics 15, 60-67. http://dx.doi.org/10.2307/1392074

Hansen, R.S. (2001). Do investment banks compete in IPOs?: the advent of the "7\% plus contract. Journal of Financial Economics 50, 313-346. http://dx.doi.org/10.1016/S0304-405X(00)00089-1

Hu, W.Y., \& Ritter, J.R. (2007). Multiple bookrunners in IPOs. University of Florida Working Paper.

Iskoz, S. (2003). Bias in underwriter analyst recommendations: does it matter? Massachusetts Institute of Technology Working Paper.

Jenkinson, T., \& Jones, H. (2007). The economics of IPO stabilisation, syndicates, and naked shorts. European Financial Management 13, 616-642. http://dx.doi.org/10.1111/j.1468-036X.2007.00376.x

Kadan, O., Madureira, L., Wang, R., \& Zach, T. (2009). Conflict of interest and stock recommendations: The effects of the Global Settlement and related regulations. Review of Financial Studies 22, 4189-4217. http://dx.doi.org/10.1093/rfs/hhn109

Keegan, J. (1999a). Bulge bracket beware: commercial banks now dominates some syndicates. Investment Dealers' Digest, February 8.

Keegan, J. (1999b). As details of AT\&T issue emerge, tiny Blaylock wins coveted slot. Investment Dealers' Digest, March 8.

Krigman, L. Shaw, W.H., \& Womack, K.L. (1999). The persistence of IPO mispricing and the predicative power of flipping. Journal of Finance 54, 1015-1044. http://dx.doi.org/10.1111/0022-1082.00135

Krigman, L. Shaw, W.H., \& Womack, K.L. (2001). Why do firms switch underwriters? Journal of Financial Economics 60, 245-284. http://dx.doi.org/10.1016/S0304-405X(01)00045-9

Kuhn, R.L. (1990). Investment banking: The art and science of high-stake dealmaking. Harper \& Row, New York, NY. 
Lee, C., Jeon, J.Q., \& Kim, B.J. (2011). Reciprocity in syndicate participation and issuer's welfare: Evidence from Initial Public Offerings. Asia-Pacific Journal of Financial Studies 40, 138-198. http://onlinelibrary.wiley.com/doi/10.1111/j.2041-6156.2011.01036.x/abstract

Ljungqvist, A.P., Jenkinson, T., \& Wilhelm, W.J. (2003). Global integration in primary equity markets: the role of U.S. banks and U.S. investors. Review of Financial Studies 16, 63-99. http://dx.doi.org/10.1093/rfs/16.1.63

Ljungqvist, A.P., Marston, F.C., \& Wilhelm, W.J. (2009). Scaling the hierarchy: how and why investment banks compete for syndicate co-management appointments. Review of Financial Studies 22, 3977-4007. http://dx.doi.org/10.1093/rfs/hhn106

Loughran, T., \& Ritter, J.R. (2004). Why has IPO underpricing changed over time? Financial Management 33, 5-31. McNichols, M., O'Brien, P.C., \& Pamukcu, O.M. (2006). That ship has sailed: unaffiliated analysts' recommendation performance for IPO firms. Stanford University Working Paper.

Michaely, R., \& Womack, K.L. (1999). Conflict of interest and the credibility of underwriter analyst recommendations. Review of Financial Studies 12, 653-686. http://dx.doi.org/10.1093/rfs/12.4.653

Pichler, P., \& Wilhelm, W. (2001). A theory of the syndicate: form follows function. Journal of Finance 56, 2237-2264. http://dx.doi.org/10.1111/0022-1082.00404

Picker, I. (1998). No more sticky fees: competition may finally bring down the cost of equity offering. Institutional Investor, 32(9), September, New York, NY.

Rajan, R., \& Servaes, H. (1997). Analyst following of initial public offerings. Journal of Finance 52, 507-529.

Schultz, P., \& Zaman, M. (2001). Do the individuals closest to internet firms believe they are overvalued? Journal of Financial Economics 59, 347-381. http://dx.doi.org/10.1016/S0304-405X(00)00090-8

Security Industry Association. (2005). Capital Markets Handbook 6th edition, edited by John C. Burch, Jr. and Bruce S. Foerster, Aspen Publishers, New York, NY.

Stickel, S.E. (1992). Reputation and performance among security analysts. Journal of Finance 47, 1811-1836.

Torstila, S. (2001). The distribution of fees within the IPO syndicate. Financial Management 30, 35-43. http://dx.doi.org/10.2307/3666257

Torstila, S. (2003). The clustering of IPO gross spreads: international evidence. Journal of Financial and Quantitative Analysis 38, 673-694. http://dx.doi.org/10.2307/4126736

Tunick, B., \& Hahn, A.L. (2001). Tri books: a bear hug? Merrill, J. P. Morgan and UBS share Sprint deal. Investment Dealers' Digest, August 13.

Wirth, G. (1997). Is this the death of the syndicate? Investment Dealer's Digest 63, 20-23.

\section{Notes}

Note 1. For instance, Kuhn (1990, p. 146) says "The most significant normal source of investment banking revenue is from arranging public offerings."

Note 2. Rajan and Servaes (1997) also find that analyst coverage is positively associated with underpricing. Bradley et al. (2008) demonstrate that during the bubble period there is a positive relationship between analyst coverage and underpricing at the end of the quiet period but the relationship dissipates quickly after the quiet period. Loughran and Ritter (2004) suggest the analyst lust hypothesis in which analyst coverage is compensated through underpricing since, despite its increasing importance, there is no explicit compensation for it. Krigman et al. (2001) and Cliff and Denis (2004) also find evidence that analyst coverage is a critical determinant when issuers decide to switch lead underwriters from IPOs to SEOs (seasoned equity offerings).

Note 3. Like the widespread $7 \%$ gross spread, the $20 / 20 / 60$ split of the gross spread ( $20 \%$ management fee, $20 \%$ underwriting fee, and $60 \%$ selling concession) is also prevalent and considered by many to be the industry standard. Torstila (2001) notes, however, that there is a substantial variation in the split. In our sample, the 20/20/60 split comprises only $11 \%$ of the sample whereas the exact $7 \%$ gross spread occurs in $82 \%$. 
Note 4. Michaely and Womack (1999, p. 654) state “...implicit in the underwriter-issuer relationship is the underwriter's intention to follow the newly issued security in the aftermarket: that is, to provide (presumably positive) analyst coverage." However, since underpricing cannot be predicted with certainty at the time of choosing a lead underwriter, we feel that the compensation for implicit pre-commitment on analyst coverage is highly likely to be bundled into the gross spread.

Note 5. The fixed economics is to normally split the gross spread net of underwriting expenses based solely on underwriting commitment among underwriters, with no relation to the gross spread split into three components. Section Syndicate Economics provides a detailed discussion on the fixed economics.

Note 6. Jay Ritter informed us and provided comments on the fixed economics during the 2007 FMA conference and provided additional information after the conference. Jay Ritter's investment banker friend also indicates that it became common by the late 1999s, which is consistent with the breakpoint test result.

Note 7. Chen and Ritter (2001) and Hansen (2001) analyze the 7\% gross spread in the U.S. while Ljungqvist et al. (2003) and Torstila (2003) evaluate the international evidence.

Note 8. This section heavily draws on Security Industry Association, 2005, Capital Markets Handbook 6th edition.

Note 9. The split of the selling concession can be fixed from inception, or can be determined by a combination of fixed and competitive splits. Exemplary deal economics is found in Chen and Ritter (2000, Table V) and Torstila (2001, Table I). More detailed illustrative deal economics is in "Re: Comments on Amendments to Regulation M: Anti-manipulation Rules Concerning Security Offerings.-File Number S7-41-04" (http://www.sec.gov/rules/proposed/ s74104/burch021505.pdf).

Note 10. The institutional pot is a mechanism for institutional investor shares to be ordered and stored but not in any specific underwriters' accounts. This mechanism can be convenient in the case of large order sizes that would have required multiple order confirmations with multiple underwriters. It also provides information to institutional investors on demand. The lead underwriter fully influences how shares are allocated to institutions in the pot and receives the majority of selling concession generated from the pot. Types of institutional pots include jump ball or competitive pot, capped jump ball pot, open pot, fixed compensation pot, and incentive or performance pot. Panel B of Table V in Chen and Ritter (2000) illustrates an 'institutional pot' allocation in the breakdown of share allocation. See $\S 5.09$ of Capital Markets Handbook for more details.

Note 11. Jay Ritter additionally notes that the actual fixed economics split is not publicly disclosed. The example in this section is a slightly modified version of the example provided by Jay Ritter.

Note 12. The number of cold IPOs is $352(18.6 \%)$ in our sample if we define offerings with the zero or negative first-day initial return as cold IPOs following Krigman et al. (1999).

Note 13. We can extend this example to the pre-fixed economics period after assuming that the lead underwriter (each co-manager) sells $80 \%$ (15\% each) and receives $50 \%(25 \%$ each) of the management fee. Let's further assume that we have the 20/20/60 gross spread split and there is no underwriting expense (road show and other costs) for simplicity. Under these circumstances, the lead underwriter receives $72 \%$ of the gross spread $(72 \%=50 \% \times 20 \%$ (management fee) $+70 \% \times 20 \%$ (underwriting fee) $+80 \% \times 60 \%$ (selling concession)) while each co-manager receives $14 \%(14 \%=25 \% \times 20 \%$ (management fee) $+15 \% \times 20 \%$ (underwriting fee) $+10 \% \times 60 \%$ (selling concession)). Refer to equation (1) in the following section for the payoff function for the underwriter in the pre-fixed economics period.

Note 14. Corwin and Schultz (2005) cite from the Capital Markets Handbook that sales credited for co-managers and other syndicate members are typically only $10 \%$ of the shares underwritten, although this can be enhanced by services provided by syndicate members such as analyst coverage.

Note 15 . We cannot perform the same analysis for co-manager affiliated coverage because we do not have sufficient information related to underwriting expenses and sales credited.

Note 16. I/B/E/S recommendations data are available from the fourth quarter of 1993. Our sample period ends in June 2002 for the following two reasons. First, multiple lead underwriter IPOs became visible after 2001, reached 50\% in 2005 , and peaked at $86 \%$ in 2009, as is shown in table 11 in "IPO Statistics for 2010 and Earlier Years" in Jay Ritter's web-site (http://bear.warrington.ufl.edu/ritter/IPOs2010Statistics111.pdf). If we increase our sample to a later year than 2002, we will lose substantial observations due to increasing multiple lead underwriter IPOs especially in recent years, which would make our analysis after removing those IPOs less representative. The other reason is of legal issues. In response to the enactment of Section 501 in the Sarbanes-Oxley Act of 2002, the Securities Exchange Committee (SEC) approved a new rule for the National Association of Securities Dealers 
(NASD), Rule 2711, and amended the New York Stock Exchange (NYSE) Rule 472 [See Securities Exchange Act Release No. 45908 (May 10, 2002) 67 FR 34968 (May 16, 2002)]. These rule changes, intended to address research analyst conflicts of interest, were enforced from July 2002. Thus, to maintain homogeneity in regulation perspective on analyst coverage, we end our sample period in June 2002. For the same reason, Corwin and Schultz (2005) and Ljungqvist et al. (2009) end their samples in June 2002.

Note 17. Our descriptions on manager roles are based on the SDC data team's description. The term, bookrunner is often used interchangeably with book manager and lead underwriter. Throughout this study, we use the term 'lead underwriter' to refer to these roles.

Note 18. Capital Markets Handbook states, on $\S 2.08$, "If there is more than one underwriting tranche, the lead manager [lead underwriter] usually acts as global coordinator as well and...."

Note 19. Chapters 3 to 5 in Capital Markets Handbook describe in detail the roles of the lead underwriter (bookrunner).

Note 20. SDC defines a lead manager as "anyone who is a bookrunner [lead underwriter], a joint bookrunner, or a joint lead manager."

Note 21. Jim Cowles, head of global equity capital markets at Salomon Smith Barney, is quoted as saying "Typically, it doesn't cost an issuer any more to put in more co-managers" (Picker, 1998). On the other hand, from the lead underwriter's perspective, Corwin and Shultz (2005, pp. 444-5) provide several reasons why syndicate size is limited.

Note 22. The section is initiated by Jay Ritter's comments at the 2007 FMA conference. We really appreciate his invaluable comments.

Note 23. We place results based on combined recommendations here as part of robustness tests rather than putting these results in the main body for the following reason: although Bradley, Jordan, and Ritter (2008) found that $\mathrm{I} / \mathrm{B} / \mathrm{E} / \mathrm{S}$ does not capture all recommendations and used combined recommendations, majority of the previous and subsequent researches are based only on I/B/E/S, such as Kadan, Madureira, Wang, and Zach (2009) and Ljungqvist, Marston, Wilhelm (2009). Even the authors $\neg \_$Bradley, Jordan, and Ritter —used I/B/E/S only for majority of their subsequent researches.

Note 24. There is usually a discrepancy between time stamps in I/B/E/S, First Call, and Briefing.com. We regard a recommendation in First Call or Briefing.com as a missing recommendation from $\mathrm{I} / \mathrm{B} / \mathrm{E} / \mathrm{S}$ when we have a time difference more than a month for the same kind of recommendation by the same broker (underwriter). Otherwise, we consider them identical.

Note 25. To meet the exclusion restrictions for identification, we add ln (1+Firm Age), VC-backed Dummy, Offer Price Revision, and Major Market Dummy — which are also used by Cliff and Denis (2004) for the analyst coverage estimation in Table VI - to the 1st stage probit regression, but not to the 2nd state OLS estimation. The basic specification for the treatment-effects model is based on the one in Table 7.

Note 26. $\lambda$ 's p-value is 0.61 . We also try the maximum likelihood estimation (MLE) and again find no evidence for the bias. The $\chi 2$ statistic for LR test $(\rho=0)$ is 0.31 ( $p$-value $=0.58$ ).

Note 27. Corwin and Schultz (2005) find that the most important factor for syndicate participation is whether the current co-manager has participated in recent syndicates led by the same lead underwriter in the current syndicate and, as importantly, whether the current lead underwriter has participated as a co-manager in recent syndicates led by the current co-manager. We call mutual joint syndicate participation as 'prior relationship.'

Note 28. We follow Lee et al. (2011) for the construction of those prior relationship variables, and use their appendix and Corwin and Schultz's (2005) appendix together in order to adjust for name changes due to M\&As (mergers and acquisitions) or other reasons. 
Table 1. Descriptive Statistics

\begin{tabular}{|c|c|c|c|c|c|c|}
\hline \multicolumn{7}{|c|}{ Panel A: Distribution of Sample Characteristics } \\
\hline Variable & Obs. & Mean & Stdev & Min & Median & $\operatorname{Max}$ \\
\hline Firm Age & 1,894 & 13.31 & 18.91 & 0 & 7 & 151 \\
\hline Offer Proceeds (\$ millions) & 1,894 & 81 & 170 & 20 & 48 & 3,960 \\
\hline Gross Spread (\$ millions) & 1,894 & 5.5 & 7.9 & 1.4 & 3.7 & 160.0 \\
\hline$\%$ Gross Spread & 1,894 & $6.86 \%$ & 0.0045 & $2.5 \%$ & $7 \%$ & $8.25 \%$ \\
\hline Management Fee & 1,894 & $20.31 \%$ & $1.46 \%$ & $14.29 \%$ & $20.17 \%$ & $60.00 \%$ \\
\hline Underwriting Fee & 1,894 & $21.25 \%$ & $2.06 \%$ & $14.58 \%$ & $20.54 \%$ & $35.71 \%$ \\
\hline Selling Concession & 1,894 & $58.44 \%$ & $2.56 \%$ & $19.39 \%$ & $59.26 \%$ & $65.63 \%$ \\
\hline No. of Co-managers & 1,893 & 1.96 & 1.17 & 0 & 2 & 22 \\
\hline Syndicate Size & 1,893 & 10.71 & 9.62 & 1 & 8 & 61 \\
\hline LU Reputation & 1,894 & 7.98 & 1.18 & 1 & 8 & 9 \\
\hline LU Recommendations & 1,894 & 0.88 & 1.07 & 0 & 1 & 7 \\
\hline No. of Recommendations & 1,894 & 7.44 & 5.35 & 1 & 6 & 44 \\
\hline \%Affiliated Coverage & 1,894 & $16.13 \%$ & 0.22 & $0 \%$ & $7.69 \%$ & $100 \%$ \\
\hline Underpricing & 1,885 & $32 \%$ & $59 \%$ & $-88 \%$ & $14 \%$ & $606 \%$ \\
\hline
\end{tabular}

Panel B: Number of Observations (Sample Size=1,894)

\begin{tabular}{|c|c|c|c|c|c|}
\hline & $\mathrm{N}$ & $(\%)$ & & $\mathrm{N}$ & $(\%)$ \\
\hline NYSE IPOs & 281 & $(15 \%)$ & $\%$ Gross Spread < 7\% & 293 & $(15 \%)$ \\
\hline AMEX IPOs & 17 & $(1 \%)$ & $\%$ Gross Spread = 7\% & 1,551 & $(82 \%)$ \\
\hline Nasdaq IPOs & 1,563 & $(83 \%)$ & $\%$ Gross Spread > 7\% & 50 & $(3 \%)$ \\
\hline Internet IPO Dummy & 317 & $(17 \%)$ & Affiliated Coverage Dummy & 979 & $(52 \%)$ \\
\hline
\end{tabular}

The table summarizes descriptive statistics of our sample in Panels A and B. The sample consists of 1894 U.S. IPOs from October 1993 to June 2002. We obtain IPO and syndicate data from SDC and stock prices from CRSP. Firm Age is the difference in years between the year of the IPO and the year of founding. Offer Proceeds are the number of shares times the offer price, excluding any overallotment option. Gross Spread is the actual total dollar amount of the gross spread in each IPO. \%Gross Spread is the percentage of Gross Spread relative to Offer Proceeds. Management Fee, Underwriting Fee, and Selling Concession are the percentage out of the Gross Spread, respectively. No. of Co-managers is the number of co-managers in an IPO syndicate. Syndicate Size is the total number of lead underwriter, co-managers, and syndicate members. LU Reputation is the adjusted Carter-Manaster (1990) rank for the lead underwriter available at Jay Ritter's web-site. LU Recommendation is the number of recommendations issued by the lead underwriter for 1 year horizon after the IPO. No. of Recommendations is the number of recommendations on an issuer for 1 year horizon after the IPO. \%Affiliated Coverage is the percentage of recommendations by lead underwriter affiliated analysts in overall recommendations within 1 year of the IPO. Underpricing is the first-day return calculated by the percentage change from the offer price from SDC to the first trading day closing price from CRSP. NYSE IPOs, AMEX IPOs, Nasdaq IPOs are the number of IPOs issued in each exchange. Internet IPO Dummy is one if an IPO belongs to one of the SIC codes for the internet IPO firms provided in Jay Ritter's web-page and zero otherwise. Affiliated Coverage Dummy is one if an IPO has a recommendation by any lead underwriter affiliated analyst and zero otherwise. 
Table 2. Yearly Breakdown of Sample Characteristics

\begin{tabular}{|c|c|c|c|c|c|c|c|c|c|c|}
\hline Variable & 1993 & 1994 & 1995 & 1996 & 1997 & 1998 & 1999 & 2000 & 2001 & 2002 \\
\hline No. of IPOs & 64 & 158 & 252 & 382 & 274 & 168 & 309 & 236 & 28 & 23 \\
\hline Firm Age & 20.4 & 17.7 & 13.7 & 13.3 & 15.9 & 14.0 & 8.5 & 10.1 & 15.1 & 20.3 \\
\hline Offer Proceeds ( $\$$ millions) & 54 & 58 & 64 & 61 & 67 & 120 & 100 & 97 & 140 & 140 \\
\hline Gross Spread (\$ millions) & 3.9 & 4.0 & 4.6 & 4.5 & 4.7 & 6.8 & 6.7 & 7.1 & 9.4 & 11 \\
\hline$\%$ Gross Spread & $6.82 \%$ & $6.80 \%$ & $6.84 \%$ & $6.89 \%$ & $6.82 \%$ & $6.82 \%$ & $6.90 \%$ & $6.92 \%$ & $6.79 \%$ & $6.83 \%$ \\
\hline Management Fee & $20.46 \%$ & $20.28 \%$ & $20.39 \%$ & $20.35 \%$ & $20.32 \%$ & $20.49 \%$ & $20.24 \%$ & $20.09 \%$ & $20.22 \%$ & $20.28 \%$ \\
\hline Underwriting Fee & $21.41 \%$ & $21.98 \%$ & $21.50 \%$ & $21.44 \%$ & $21.67 \%$ & $21.42 \%$ & $20.78 \%$ & $20.43 \%$ & $20.19 \%$ & $19.79 \%$ \\
\hline Selling Concession & $58.13 \%$ & $57.73 \%$ & $58.11 \%$ & $58.21 \%$ & $58.02 \%$ & $58.09 \%$ & $58.98 \%$ & $59.47 \%$ & $59.59 \%$ & $59.93 \%$ \\
\hline No. of Co-managers & 1.33 & 1.42 & 1.54 & 1.67 & 1.72 & 2.14 & 2.54 & 2.61 & 2.82 & 3.04 \\
\hline Syndicate Size & 2.33 & 2.42 & 2.54 & 3.12 & 19.09 & 18.51 & 16.22 & 14.78 & 13.14 & 11.35 \\
\hline LU Reputation & 8.22 & 8.04 & 8.06 & 8.05 & 7.71 & 7.56 & 7.99 & 8.21 & 8.13 & 8.03 \\
\hline No. of Recommendations & 4.84 & 5.56 & 6.21 & 7.56 & 6.33 & 8.01 & 9.44 & 7.92 & 9.32 & 14.26 \\
\hline \%Affiliated Coverage & $17.4 \%$ & $17.8 \%$ & $17.7 \%$ & $16.1 \%$ & $13.6 \%$ & $12.0 \%$ & $8.5 \%$ & $7.6 \%$ & $13.5 \%$ & $11.4 \%$ \\
\hline Affiliated Coverage Dummy & $58 \%$ & $66 \%$ & $62 \%$ & $64 \%$ & $44.5 \%$ & $42.3 \%$ & $40.8 \%$ & $36.0 \%$ & $57.1 \%$ & $69.6 \%$ \\
\hline Underpricing & $10.0 \%$ & $10.3 \%$ & $22.7 \%$ & $18.0 \%$ & $15.8 \%$ & $27.9 \%$ & $74.4 \%$ & $57.2 \%$ & $18.7 \%$ & $6.3 \%$ \\
\hline
\end{tabular}

The table presents sample characteristics by year. The sample consists of 1894 U.S. IPOs from October 1993 to June 2002 . We obtain IPO and syndicate data from SDC and stock prices from CRSP. Firm Age is the difference in years between the year of the IPO and the year of founding. Offer Proceeds are the number of shares times the offer price, excluding any overallotment option. Gross Spread is the actual total dollar amount of the gross spread in each IPO. \%Gross Spread is the percentage of Gross Spread relative to Offer Proceeds. Management Fee, Underwriting Fee, and Selling Concession are the percentage out of the Gross Spread, respectively. No. of Co-managers is the number of co-managers in an IPO syndicate. Syndicate Size is the total number of lead underwriter, co-managers, and syndicate members. LU Reputation is the adjusted Carter-Manaster (1990) rank for the lead underwriter available at Jay Ritter's web-site. No. of Recommendations is the number of recommendations on an issuer for 1 year horizon after the IPO. \%Affiliated Coverage is the percentage of recommendations by lead underwriter affiliated analysts in overall recommendations within 1 year of the IPO. Affiliated Coverage Dummy is one if an IPO has a recommendation by any lead underwriter affiliated analyst and zero otherwise. Underpricing is the first-day return calculated by the percentage change from the offer price from SDC to the first trading day closing price from CRSP.

Table 3. Seemingly Unrelated Regression (SUR) Estimation Results: Overall Sample

\begin{tabular}{|c|c|c|c|}
\hline & Dependent Variables & & \\
\hline & Management Fee & Underwriting Fee & Selling Concession \\
\hline Affiliated Coverage Dummy & $-0.00074 \quad(-1.06)$ & 0.00041 & 0.00033 \\
\hline LU Reputation & $-0.00083 \quad(-2.7) * * *$ & $-0.00136 \quad(-3.43) * * *$ & $(4.37) * * *$ \\
\hline Gross Spread & $-0.00002 \quad(-0.22)$ & $-0.00112 \quad(-8.99) * * *$ & $(7.24) * * *$ \\
\hline$(\text { Gross Spread })^{2}$ & 0.00000 & $(6.51) * * *$ & $-0.00001 \quad(-5.25) * * *$ \\
\hline No. of Co-managers & -0.00004 & $-0.00071 \quad(-1.43)$ & 0.00075 \\
\hline Underpricing & -0.00048 & $-0.00353(-4.05) * * *$ & $(3.64) * * *$ \\
\hline Aftermarket Stdev & 0.00061 & $-0.01566 \quad(-4.62) * * *$ & $(3.51) * * *$ \\
\hline Internet IPO Dummy & $0.00068 \quad(0.58)$ & -0.00253 & 0.00185 \\
\hline Intercept, year dummies, and & try dummies are included & & \\
\hline$R^{2}$ & 0.0146 & 0.1728 & 0.1406 \\
\hline No. of Observations & 1,884 & 1,884 & 1,884 \\
\hline
\end{tabular}

The table presents the results from the SUR estimation using the overall sample (October 1993-June 2002). Management Fee, Underwriting Fee, and Selling Concession are the percentage out of the Gross Spread, respectively. Affiliated Coverage Dummy is one if an IPO has a recommendation by any lead underwriter affiliated analyst and zero otherwise. LU Reputation Rank is the adjusted Carter-Manaster (1990) rank for the lead underwriter available at Jay Ritter's web-site. Gross Spread is the total dollar amount of the gross spread and is in millions of dollars. No. of Co-managers is the number of the co-managers in an IPO syndicate. Underpricing is the first-day return calculated by the percentage change from the offer price from SDC to the first trading day closing price from CRSP. Aftermarket Stdev is calculated with compounded returns from $21^{\text {st }}$ to $125^{\text {th }}$ trading day as in Corwin and Schultz (2005). Internet IPO Dummy is one if an IPO belongs to one of the SIC codes for the internet IPO firms provided in Jay Ritter's web-page and zero otherwise. $t$-statistics are reported in parentheses. * ${ }^{* *}$, and $* * *$ indicate significance levels at the $10 \%, 5 \%$, and $1 \%$, respectively. 
Table 4. Quandt-Andrews Unknown Breakpoint Test: Pre-fixed vs. Fixed economics Periods

\begin{tabular}{llllllll}
\hline $\begin{array}{l}\text { No. of Breaks } \\
\text { Compared }(k)\end{array}$ & Maximum LR & & Exponential & & Average & \multicolumn{2}{l}{ Time of } \\
L-statistic & & LR $F$-statistic & & LR $F$-statistic & Break \\
\hline 904 & $28.1436(0.0197)$ & $* *$ & $12.2613(0.0056)$ & $* * *$ & $22.2507(0.0005)$ & $* * *$ & June 161998 \\
516 & $28.1436(0.0115)$ & $* *$ & $12.7194(0.0036)$ & $* * *$ & $24.0619(0.0008)$ & $* * *$ & June 161998 \\
258 & $28.1436(0.0065)$ & $* * *$ & $13.1432(0.0022)$ & $* * *$ & $25.3707(0.0011)$ & $* * *$ & June 161998 \\
24 & $27.9845(0.0021)$ & $* * *$ & $13.6161(0.0013)$ & $* * *$ & $27.1990(0.0012)$ & $* * *$ & June 171998 \\
\hline
\end{tabular}

The table provides the results from the Quandt-Andrews unknown breakpoint test in order to bifurcate our sample period into the pre-Fixed Economics period and the Fixed Economics period. The specification used in this test is given by:

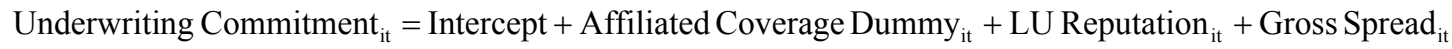

$$
\begin{aligned}
& +\left(\text { Gross Spread }_{\mathrm{it}}^{2}+\text { No. of Co - managers }_{\mathrm{it}}+\text { No. of Syndicate Members }_{\mathrm{it}}\right. \\
& + \text { Underpricing }_{\mathrm{it}}+\text { Aftermarket Stdev }_{\mathrm{it}}+\text { Internet IPO }_{\mathrm{it}}+\varepsilon_{\mathrm{t}}
\end{aligned}
$$

$i$ denotes underwriter $i$ and $t$ is the IPO date for the underwriter. Underwriting Commitment is the percentage of the shares that the lead underwriter underwrites relative to the total number of shares issued. Affiliated Coverage Dummy is one if an IPO has a recommendation by any lead underwriter affiliated analyst and zero otherwise. LU Reputation is the adjusted Carter-Manaster (1990) rank for the lead underwriter available at Jay Ritter's web-site. Gross Spread is the total dollar amount of the gross spread and is in millions of dollars. No. of Co-managers is the number of the co-managers in an IPO syndicate. No. of Syndicate Members is the number of the syndicate members in a syndicate. Underpricing is the first-day return calculated by the percentage change from the offer price from SDC to the first trading day closing price from CRSP. Aftermarket Stdev is calculated with compounded returns from $21^{\text {st }}$ to $125^{\text {th }}$ trading day as in Corwin and Schultz (2005). Internet IPO Dummy is one if an IPO belongs to one of the SIC codes for the internet IPO firms provided in Jay Ritter's web-page and zero otherwise. Each $F$-statistic in the table is given below by:

$$
\operatorname{Max} F=\max _{\tau_{1} \leq \tau \leq \tau_{2}}[F(\tau)] \quad \operatorname{Exp} F=\ln \left(\frac{1}{k} \sum_{\tau_{1}}^{\tau_{2}} \exp \left[\frac{1}{2} F(\tau)\right]\right) \quad \operatorname{Avg} F=\frac{1}{k} \sum_{\tau_{1}}^{\tau_{2}} F(\tau)
$$

$\tau$ is a potential breakpoint that we consider for the structural break; $\tau_{1}$ and $\tau_{2}$ are the starting and ending time points that we consider for the structural break; $k$ is the number of breaks compared. Assigning a specific interval for the test determines the number of structural breaks that the test examines. The first column shows the number of structural breaks in relation to different test intervals. LR denotes the likelihood ratio. Hansen (1997)'s approximate asymptotic $p$-values are reported in parentheses. *, **,

\begin{tabular}{|c|c|c|c|c|c|c|c|c|c|c|c|c|}
\hline \multirow{3}{*}{$\begin{array}{l}\text { Sample } \\
\text { All }\end{array}$} & \multirow{3}{*}{$\begin{array}{l}\text { Affiliated } \\
\text { Coverage } \\
\text { Yes } \\
\text { No }\end{array}$} & \multirow{3}{*}{$\begin{array}{l}\text { Obs. } \\
979 \\
915\end{array}$} & \multicolumn{2}{|c|}{ Management Fee } & \multicolumn{2}{|c|}{ Underwriting Fee } & \multicolumn{2}{|c|}{ Selling Concession } & \multicolumn{2}{|r|}{ Obs. } & \multicolumn{2}{|c|}{$\begin{array}{l}\text { Underwriting } \\
\text { Commitment }\end{array}$} \\
\hline & & & $20.28 \%$ & & $21.29 \%$ & & $58.43 \%$ & & & 604 & $33.22 \%$ & \\
\hline & & & $20.34 \%$ & $(-0.91)$ & $21.22 \%$ & & $58.44 \%$ & & & 692 & $33.71 \%$ & \\
\hline \multirow{2}{*}{ Pre-FE } & Yes & 706 & $20.33 \%$ & \multirow{2}{*}{$(-1.28)$} & $21.48 \%$ & \multirow{2}{*}{$(-1.82)$} & $58.19 \%$ & \multirow{2}{*}{$(2.26)$} & & 331 & $29.07 \%$ & \multirow{2}{*}{$(0.60)$} \\
\hline & No & 529 & $20.43 \%$ & & $21.69 \%$ & & $57.88 \%$ & & & 306 & $28.60 \%$ & \\
\hline \multirow{2}{*}{ FE } & Yes & 273 & $20.14 \%$ & \multirow{2}{*}{$(-0.63)$} & $20.79 \%$ & \multirow{2}{*}{$(1.42)$} & $59.09 \%$ & \multirow{2}{*}{$(-0.67)$} & & 273 & $38.24 \%$ & \multirow{2}{*}{$(0.37)$} \\
\hline & No & 386 & $20.22 \%$ & & $20.57 \%$ & & $59.21 \%$ & & & 386 & $37.76 \%$ & \\
\hline
\end{tabular}
and $* * *$ indicate significance levels at the $10 \%, 5 \%$, and $1 \%$, respectively.

Table 5. Univariate Tests of Affiliated Coverage by Sample Period

The table reports univariate test results according to whether the IPO receives affiliated coverage using 1,894 sample IPOs. Affiliated Coverage is Yes if an IPO receives affiliated coverage and No otherwise. Management Fee, Underwriting Fee, and Selling Concession are the percentage out of the Gross Spread, respectively. Underwriting Commitment is the percentage of the shares that the lead underwriter underwrites relative to the total number of shares issued. Pre-FE includes IPOs in the pre-fixed economics period from October 1 to June 16 1998. FE includes IPOs in the fixed economics period since June 17 1998. Mean values for each fee and Underwriting Commitment are reported with $t$-statistics from $t$-tests in parentheses. *, **, and *** indicate significance levels at the $10 \%, 5 \%$, and $1 \%$, respectively. 
Table 6. SUR Regression Results in the Pre-fixed Economics Period: High vs. Low Sub-samples

\begin{tabular}{|c|c|c|c|c|c|c|c|c|c|}
\hline & \multicolumn{9}{|c|}{ Dependent Variables } \\
\hline & \multicolumn{3}{|c|}{ Management Fee } & \multicolumn{2}{|c|}{ Underwriting Fee } & \multicolumn{4}{|c|}{ Selling Concession } \\
\hline \multicolumn{10}{|c|}{ Panel A: SUR Estimation Results for the Overall sample in the Pre-Fixed Economics Period } \\
\hline Affiliated Coverage Dummy & -0.00178 & $(-1.26)$ & & -0.00323 & $(-2.13)$ & $* *$ & 0.00500 & $(2.47)$ & ** \\
\hline LU Reputation & -0.00203 & $(-3.16)$ & $* * *$ & -0.00023 & $(-0.34)$ & & 0.00227 & $(2.45)$ & $* *$ \\
\hline Gross Spread & -0.00026 & $(-0.61)$ & & -0.00287 & $(-6.35)$ & $* * *$ & 0.00313 & $(5.18)$ & $* * *$ \\
\hline$(\text { Gross Spread })^{2}$ & 0.00000 & $(0.28)$ & & 0.00006 & $(4.56)$ & $* * *$ & -0.00007 & $(-3.61)$ & $* * *$ \\
\hline No. of Co-managers & 0.00108 & $(1.11)$ & & -0.00043 & $(-0.41)$ & & -0.00065 & $(-0.46)$ & \\
\hline Underpricing & 0.00341 & $(1.08)$ & & -0.00576 & $(-1.7)$ & $*$ & 0.00236 & $(0.52)$ & \\
\hline Aftermarket Stdev & 0.00046 & $(0.09)$ & & -0.02279 & $(-4.07)$ & $* * *$ & 0.02233 & (2.99) & $* * *$ \\
\hline Internet IPO Dummy & -0.00029 & $(-0.08)$ & & -0.00263 & $(-0.65)$ & & 0.00292 & $(0.54)$ & \\
\hline \multicolumn{10}{|c|}{ Intercept, year dummies, and industry dummies are included } \\
\hline$R^{2}$ & 0.0324 & & & 0.1690 & & & 0.1319 & & \\
\hline No. of Observations & 635 & & & 635 & & & 635 & & \\
\hline \multicolumn{10}{|c|}{ Panel B: SUR Estimation Results for the High Sub-sample in the Pre-Fixed Economics Period } \\
\hline Affiliated Coverage Dummy & -0.00121 & $(-1.31)$ & & -0.00692 & $(-3.07)$ & $* * *$ & 0.00812 & $(3.4)$ & $* * *$ \\
\hline LU Reputation & -0.00117 & $(-2.99)$ & $* * *$ & -0.00041 & $(-0.42)$ & & 0.00158 & $(1.56)$ & \\
\hline Gross Spread & 0.00008 & $(0.15)$ & & -0.00574 & $(-4.2)$ & $* * *$ & 0.00566 & $(3.91)$ & $* * *$ \\
\hline$(\text { Gross Spread })^{2}$ & 0.00000 & $(0.1)$ & & 0.00022 & $(2.7)$ & $* * *$ & -0.00022 & $(-2.51)$ & $* *$ \\
\hline No. of Co-managers & 0.00012 & $(0.1)$ & & -0.00036 & $(-0.13)$ & & 0.00023 & $(0.07)$ & \\
\hline Underpricing & 0.00325 & $(1.51)$ & & -0.00452 & $(-0.86)$ & & 0.00127 & $(0.23)$ & \\
\hline Aftermarket Stdev & 0.00251 & $(0.88)$ & & -0.02158 & $(-3.09)$ & $* * *$ & 0.01907 & $(2.58)$ & $* * *$ \\
\hline Internet IPO Dummy & 0.00306 & $(1.29)$ & & -0.00164 & $(-0.28)$ & & -0.0014 & $(-0.23)$ & \\
\hline \multicolumn{10}{|c|}{ Intercept, year dummies, and industry dummies are included } \\
\hline$R^{2}$ & 0.0706 & & & 0.1857 & & & 0.1896 & & \\
\hline No. of Observations & 318 & & & 318 & & & 318 & & \\
\hline \multicolumn{10}{|c|}{ Panel C: SUR Estimation Results for the Low Sub-sample in the Pre-Fixed Economics Period } \\
\hline Affiliated Coverage Dummy & -0.00142 & $(-0.51)$ & & 0.00097 & $(0.48)$ & & 0.00044 & $(0.13)$ & \\
\hline LU Reputation & -0.00373 & $(-2.63)$ & $* * *$ & -0.0005 & $(-0.48)$ & & 0.00423 & $(2.45)$ & $* *$ \\
\hline Gross Spread & -0.00055 & $(-0.79)$ & & -0.00243 & $(-4.67)$ & $* * *$ & 0.00298 & $(3.47)$ & $* * *$ \\
\hline$(\text { Gross Spread })^{2}$ & 0.00001 & $(0.6)$ & & 0.00005 & $(3.55)$ & $* * *$ & -0.00006 & $(-2.64)$ & $* * *$ \\
\hline No. of Co-managers & -0.00029 & $(-0.13)$ & & -0.00118 & $(-0.73)$ & & 0.00147 & $(0.55)$ & \\
\hline Underpricing & 0.00246 & $(0.42)$ & & -0.00526 & $(-1.21)$ & & 0.00281 & $(0.39)$ & \\
\hline Aftermarket Stdev & -0.00515 & $(-0.34)$ & & -0.01929 & $(-1.73)$ & $*$ & 0.02445 & $(1.32)$ & \\
\hline Internet IPO Dummy & -0.00526 & $(-0.71)$ & & 0.00025 & $(0.05)$ & & 0.00499 & $(0.55)$ & \\
\hline \multicolumn{10}{|c|}{ Intercept, year dummies, and industry dummies are included } \\
\hline$R^{2}$ & 0.0628 & & & 0.2481 & & & 0.153 & & \\
\hline No. of Observations & 317 & & & 317 & & & 317 & & \\
\hline
\end{tabular}

The table presents the results from the SUR estimation using partitioned sub-samples in the pre-Fixed Economics period (October 1 1993-June 16 1998). Management Fee, Underwriting Fee, and Selling Concession are the percentage out of the Gross Spread, respectively. The overall sample is split into High and Low sub-samples based on the median of the CM/LU Ratio where CM/LU Ratio is the ratio of shares allotted to co-managers to shares allotted to the lead underwriter-i.e., CM/LU Ratio=Shares allotted to all co-managers $\div$ Shares allotted to lead underwriter. The High sub-sample has higher lead underwriter allocations relative to the Low sub-sample; High sub-sample has IPOs with CM/LU Ratio less than the median. Affiliated Coverage Dummy is one if an IPO has a recommendation by any lead underwriter affiliated analyst and zero otherwise. LU Reputation is the adjusted Carter-Manaster (1990) rank for the lead underwriter available at Jay Ritter's web-site. Gross Spread is the total dollar amount of the gross spread and is in millions of dollars. No. of Co-managers is the number of the co-managers in an IPO syndicate. Underpricing is the first-day return calculated by the percentage change from the offer price from SDC to the first trading day closing price from CRSP. Aftermarket Stdev is calculated with compounded returns from $21^{\text {st }}$ to $125^{\text {th }}$ trading day as in Corwin and Schultz (2005). Internet IPO Dummy is one if an IPO belongs to one of the SIC codes for the internet IPO firms provided in Jay Ritter's web-page and zero otherwise. $t$-statistics are reported in parentheses. ${ }^{*}, * *$, and *** indicate significance levels at the $10 \%, 5 \%$, and $1 \%$, respectively. 
Table 7. Fixed Economics Period: Logit Regressions

\begin{tabular}{|c|c|c|c|c|c|c|}
\hline \multirow[t]{2}{*}{ Sample } & Overall Sa & mple & Overall Sar & mple & High Sub-sample & Low Sub-sample \\
\hline & \multicolumn{6}{|c|}{ Dependent Variable: Affiliated Coverage Dummy } \\
\hline CM/LU Ratio & -0.307 & $(-1.72) *$ & & & & \\
\hline \multicolumn{3}{|l|}{ Underwriting Commitment } & 0.90909 & $(0.75)$ & $(3.93) * * *$ & $-0.76169(-0.94)$ \\
\hline LU Reputation & 0.398 & $(4.16) * * *$ & 0.38615 & $(4.09) * * *$ & $0.27386 \quad(2.28) * *$ & $0.65009 \quad(3.28) * * *$ \\
\hline Gross Spread & 0.022 & $(1.17)$ & 0.01333 & $(0.72)$ & $-0.02257(-0.35)$ & $0.03005 \quad(1.37)$ \\
\hline$(\text { Gross Spread })^{2}$ & 0.000 & $(-1.33)$ & -0.00015 & $(-1.02)$ & $-0.00020(-0.18)$ & $-0.00025(-1.53)$ \\
\hline No. of Co-managers & -0.080 & $(-1.17)$ & -0.11148 & $(-1.41)$ & 0.24509 & $-0.09565(-1.33)$ \\
\hline No. of Syndicate Members & 0.054 & $(4.43) * * *$ & 0.05721 & $(4.47) * * *$ & $(4.1) * * *$ & $0.03760 \quad(2.32) * *$ \\
\hline Underpricing & -0.220 & $(-0.75)$ & -0.27920 & $(-0.95)$ & $0.25337 \quad(0.53)$ & $-0.34955(-0.78)$ \\
\hline Aftermarket Stdev & 0.719 & $(0.18)$ & 1.77580 & $(0.44)$ & $-4.62263(-0.72)$ & $3.00588 \quad(0.49)$ \\
\hline \multirow[t]{2}{*}{ Internet IPO Dummy } & 0.122 & $(0.57)$ & 0.15084 & $(0.71)$ & $0.21275 \quad(0.67)$ & $0.21879 \quad(0.71)$ \\
\hline & \multicolumn{6}{|c|}{ Intercept, year dummies, and industry dummies are included } \\
\hline Wald $\chi^{2}$ ( $p$-value) & \multicolumn{2}{|c|}{$63.98(0.0000)$} & \multicolumn{2}{|c|}{$64.91(0.0000)$} & $40.46(0.0044)$ & $35.20(0.0191)$ \\
\hline Pseudo- $R^{2}$ & \multicolumn{2}{|c|}{0.0880} & \multicolumn{2}{|c|}{0.0874} & 0.1625 & 0.1169 \\
\hline No. of Observations & \multicolumn{2}{|c|}{658} & \multicolumn{2}{|c|}{658} & 327 & 324 \\
\hline
\end{tabular}

The table presents the results from the logit regressions for the overall sample and two sub-samples for the fixed economics period (June 17 1998-June 30 2002). The High sub-sample has higher lead underwriter allocations relative to the Low sub-sample. High sub-sample has IPOs with CM/LU Ratio less than the median where CM/LU Ratio is defined in Table 6. Affiliated Coverage Dummy is one if an IPO has a recommendation by any lead underwriter affiliated analyst and zero otherwise. Underwriting Commitment is the percentage of the shares that the lead underwriter underwrites relative to the total number of shares issued. LU Reputation is the adjusted Carter-Manaster (1990) rank for the lead underwriter available at Jay Ritter's web-site. Gross Spread is the total dollar amount of the gross spread and is in millions of dollars. No. of Co-managers is the number of the co-managers in an IPO syndicate. No. of Syndicate Members is the number of the syndicate members in a syndicate. Underpricing is the first-day return calculated by the percentage change from the offer price from SDC to the first trading day closing price from CRSP. Aftermarket Stdev is calculated with compounded returns from $21^{\text {st }}$ to $125^{\text {th }}$ trading day as in Corwin and Schultz (2005). Internet IPO Dummy is one if an IPO belongs to one of the SIC codes for the internet IPO firms provided in Jay Ritter's web-page and zero otherwise. $z$-statistics are obtained using the Huber/White/sandwich robust estimator and are reported in parentheses. ${ }^{*}, *$, and $* * *$ indicate significance levels at the $10 \%, 5 \%$, and $1 \%$, respectively.

Table 8. I/B/E/S only and Combined Recommendations Data

\begin{tabular}{|c|c|c|c|c|c|}
\hline \multicolumn{6}{|c|}{ Panel A: Breakdown of Combined Recommendations Data } \\
\hline I/B/E/S Only & \multicolumn{2}{|r|}{ First Call } & \multicolumn{2}{|c|}{ Briefing.com } & Combined \\
\hline 14,218 & & 6,773 & 433 & & \\
\hline \multicolumn{6}{|c|}{ Panel B: Comparison of I/B/E/S only and Combined Data } \\
\hline Data Sources & Obs. & $\begin{array}{l}\text { Overall } \\
\text { Recommendations }\end{array}$ & $\begin{array}{l}\text { Average } \\
\text { Recommendation }\end{array}$ & $\begin{array}{l}\text { Average LU } \\
\text { Recommendations }\end{array}$ & $\begin{array}{l}\text { IPOs } \\
\text { with LU Coverage }\end{array}$ \\
\hline $\mathrm{I} / \mathrm{B} / \mathrm{E} / \mathrm{S}$ only & 1,894 & 14,218 & 7.4 & 0.88 & $979(51.7 \%)$ \\
\hline Combined & 1,894 & 21,424 & 11.3 & 1.87 & $1,508(79.6 \%)$ \\
\hline
\end{tabular}

The table reports basic summary statistics of both I/B/E/S only and combined recommendations data for 1894 IPOs from October 1993 to June 2002. Panel A shows how the combined data are constructed. We begin with I/B/E/S recommendations and add non-redundant recommendations from First Call and then from Briefing.com. Panel B shows several summary statistics for $\mathrm{I} / \mathrm{B} / \mathrm{E} / \mathrm{S}$ only and combined recommendations data. 
Table 9. SUR and Logit Regression Results with Combined Recommendations Data

Panel A: SUR Estimation Results for the High Sub-sample in the Pre-Fixed Economics Period

\begin{tabular}{|c|c|c|c|}
\hline & Dependent Variables & & \\
\hline & Management Fee & Underwriting Fee & Selling Concession \\
\hline Affiliated Coverage Dummy & $-0.00124(-1.12)$ & $-0.00738 \quad(-2.71) * * *$ & $0.00862(2.98) * * *$ \\
\hline LU Reputation & $-0.00106(-2.65) * * *$ & $0.00027 \quad(0.28)$ & $0.00079 \quad(0.76)$ \\
\hline Gross Spread & $0.00006 \quad(0.11)$ & $-0.00586 \quad(-4.28) * * *$ & $0.00580 \quad(3.99) * * *$ \\
\hline$(\text { Gross Spread })^{2}$ & $0.00000(-0.03)$ & $0.00023 \quad(2.87) * * *$ & $-0.00023 \quad(-2.7) * * *$ \\
\hline No. of Co-managers & $0.00022 \quad(0.19)$ & 0.00019 & $-0.00041 \quad(-0.14)$ \\
\hline Underpricing & $0.00310 \quad(1.43)$ & $-0.00541 \quad(-1.02)$ & $0.00231 \quad(0.41)$ \\
\hline Aftermarket Stdev & $0.00246 \quad(0.86)$ & $-0.02185 \quad(-3.12) * * *$ & $0.01939 \quad(2.61) * * *$ \\
\hline Internet IPO Dummy & $0.00298 \quad(1.26)$ & $-0.00205 \quad(-0.36)$ & $-0.00091 \quad(-0.15)$ \\
\hline \multicolumn{4}{|c|}{ Intercept, year dummies, and industry dummies are included } \\
\hline$R^{2}$ & 0.0692 & 0.1805 & 0.1830 \\
\hline No. of Observations & 318 & 318 & 318 \\
\hline
\end{tabular}

Panel B: Logit Estimation Results for the High Sub-sample in Fixed Economics Period

\begin{tabular}{|c|c|c|}
\hline \multicolumn{3}{|c|}{ Dependent Variable: Affiliated Coverage Dummy } \\
\hline Underwriting Commitment & 5.49786 & $(2.09) * *$ \\
\hline LU Reputation & 0.35520 & $(2.47) * *$ \\
\hline Gross Spread & -0.75329 & $(-0.94)$ \\
\hline$(\text { Gross Spread })^{2}$ & 0.08585 & $(1.02)$ \\
\hline No. of Co-managers & 0.14196 & $(0.41)$ \\
\hline No. of Syndicate Members & 0.17372 & $(3.47) * * *$ \\
\hline Underpricing & -0.47872 & $(-0.67)$ \\
\hline Aftermarket Stdev & 8.84404 & $(0.91)$ \\
\hline Internet IPO Dummy & -0.04619 & $(-0.1)$ \\
\hline \multicolumn{3}{|c|}{ Intercept, year dummies, and industry dummies are included } \\
\hline Wald $\chi^{2}(p$-value) & \multicolumn{2}{|c|}{$40.31(0.0012)$} \\
\hline Pseudo- $R^{2}$ & \multicolumn{2}{|c|}{0.1644} \\
\hline No. of Observations & \multicolumn{2}{|l|}{318} \\
\hline \multicolumn{3}{|c|}{$\begin{array}{l}\text { The table presents the results from the SUR estimation results for the pre-fixed economics period (October } 11993-\text { June } 16 \text { 1998) } \\
\text { and logit regression results for the fixed-economics period (June } 17 \text { 1998-June } 30 \text { 2002) with the combined recommendations } \\
\text { data in the High sub-sample (see Table } 6 \text { for the construction of High and Low sub-samples). Management Fee, Underwriting Fee, } \\
\text { and Selling Concession are the percentage out of the Gross Spread, respectively. Affiliated Coverage Dummy is one if an IPO has } \\
\text { a recommendation by any lead underwriter affiliated analyst and zero otherwise. LU Reputation is the adjusted Carter-Manaster } \\
\text { (1990) rank for the lead underwriter available at Jay Ritter's web-site. Gross Spread is the total dollar amount of the gross spread } \\
\text { and is in millions of dollars. No. of Co-managers is the number of the co-managers in an IPO syndicate. Underpricing is the } \\
\text { first-day return calculated by the percentage change from the offer price from SDC to the first trading day closing price from } \\
\text { CRSP. Aftermarket Stdev is calculated with compounded returns from } 21^{\text {st }} \text { to } 125^{\text {th }} \text { trading day as in Corwin and Schultz (2005). } \\
\text { Internet IPO Dummy is one if an IPO belongs to one of the SIC codes for the internet IPO firms provided in Jay Ritter's web-page } \\
\text { and zero otherwise. Underwriting Commitment is the percentage of the shares that the lead underwriter underwrites relative to the } \\
\text { total number of shares issued. } t \text {-statistics in Panel A are reported in parentheses. } z \text {-statistics in Panel B are obtained using the } \\
\text { Huber/White/sandwich robust estimator and are reported in parentheses. } * * * \text {, and } * * * \text { indicate significance levels at the } 10 \% \text {, } \\
5 \% \text {, and } 1 \% \text {, respectively. }\end{array}$} \\
\hline
\end{tabular}



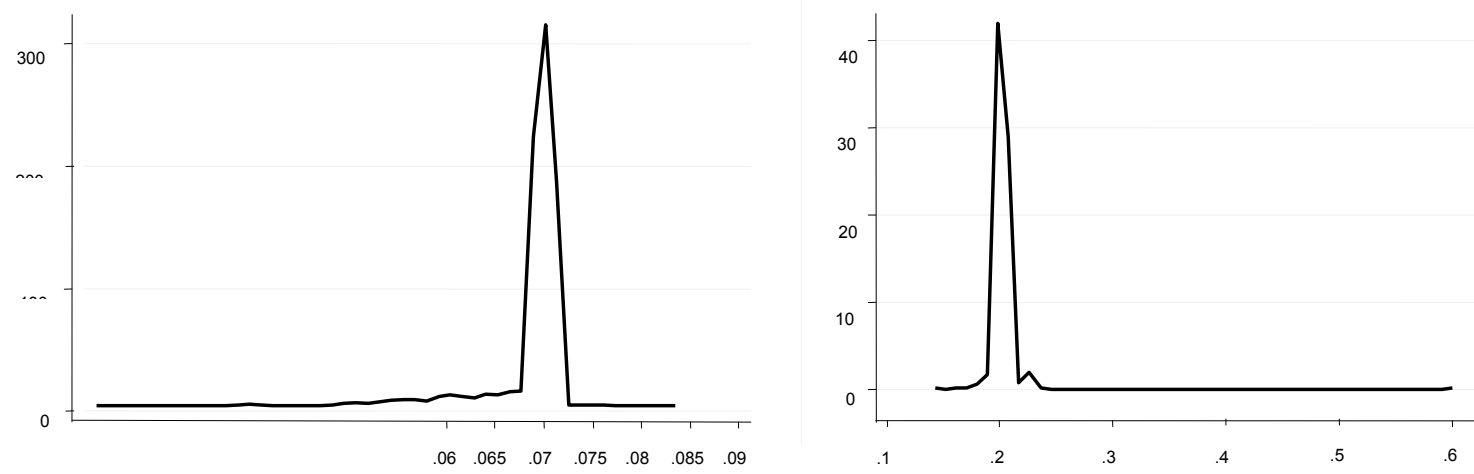

Panel A: \%Gross Spread

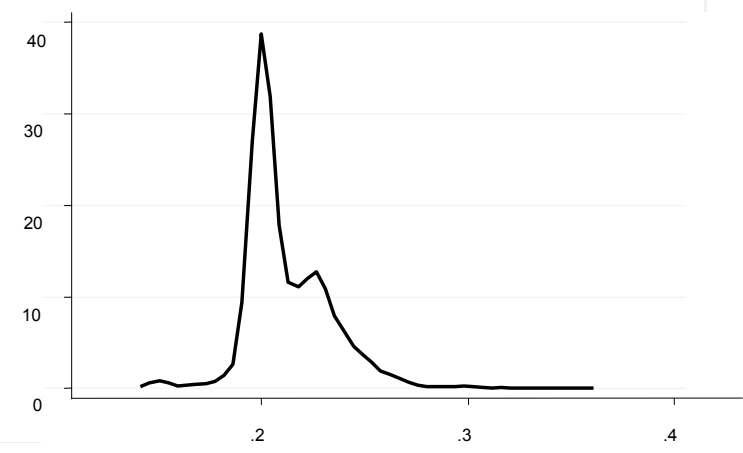

Panel C: Underwriting Fee
Panel B: Management Fee

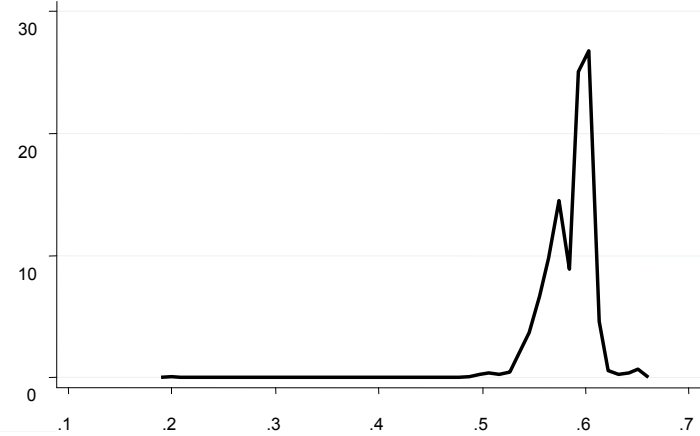

Panel D: Selling Concession

Figure 1. Gross Spread, Management Fee, Underwriting Fee and Selling Concession

Figure 1 displays sample distributions of the gross spread, management fee, underwriting fee, and selling concession. Our sample includes 1894 IPOs from October 1993 to June 2002 obtained from the SDC Platinum Global New Issues database. The gross spread is divided into three components: management fee, underwriting fee, and selling concession. Our sample has 1,551 IPOs with the exact $7 \%$ gross spread $(81.85 \%), 387$ with the exact $20 \%$ management fee $(20.43 \%), 232$ with the exact $20 \%$ underwriting fee (12.25\%), and 227 with the exact $60 \%$ selling concession (11.99\%). 